\title{
Suriyeli Mültecilerin "Misafir" Olma Haline Misafirperverlik Hukuku ve Etiği Açısından Bakış
}

\author{
CEYLAN LORTOĞLU* \\ lordogluceylan@gmail.com
}

Özet: Bu çalışmada misafirperverlik kavramı Kant’in misafirperverlik hukuku ile Derrida’nın Levinas'tan esinlenerek oluşturduğu misafirperverlik etiği düşüncesi açısından incelenmiş, Suriyeli mültecilere ${ }^{1}$ yönelik misafirlik söylemi Derrida’nın misafirperverlik düşüncesinden hareketle ele alınmıştır. Kant’in misafirperverlik düşüncesinin köklerinin bulunduğu uluslararası sözleşmelerde mültecilik hakkı devletlerin insiyatifine bırakılarak sınırlandırılmıştır. Günümüzde egemen devletlere bakıldığında uluslararası hukuku sınırlandırdıkları ve mültecilerin sınırdan geçmesini engelleyen yasa ve yönetmelikler çıkardıkları görülmüştür. Cenevre Sözleşmesine coğrafi kısıtlama şartıyla taraf olan Türkiye de iltica yasası ve politikasında sinırlamalar koymuştur. Suriyeli mültecilere yönelik geçici koruma yönetmeliği geçicilik ve mültecilerin acil ihtiyaçlarının karşılanması esası üzerinden düzenlenmiştir. Bu şekilde insan haklarından uzak, devletlerin çıkarını gözeten yasa ve politikaların dışında bir yol deneyimlemeye çalışan Derrida, koşulsuzluğu göz önünde bulundurarak yasa ve politikaların daha nasıl misafirperver yapılabileceğine dair sorgulamada bulunmuştur. Bu bağlamda misafirperverlik kavramın yapısöküme uğratmış, kavramın aporetik, çelişik ve imkansız yapısını ortaya koymuştur. Derrida’nın misafirperverlik düşüncesinden yola çıktığımızda Suriyeli mültecilere yönelik misafirlik söyleminin içinde barındırdığ çelişki, geçicilik, düşman ve istilacı imgesi, "biz" ve "onlar" ayrımı gazete haberlerinde ve toplum algısında gözlenebilmiştir. Derrida, iktidarı barındıran böylesi bir koşullu misafirperverliğin eşik, kapı olduğunu dolayısıyla misafirperverlik olmadığın belirtmiştir.

Anahtar kelimeler: Kant, Derrida, Levinas, Misafirperverlik, Etik, Hukuk, Suriyeli Mülteci.

\section{Giriş}

Sığınmave mülteci kavramlarıtarih boyuncavarolup, eskitoplumların geleneklerinde, yazıtlarında ve kutsal kitaplarında yer almıştır. Semavi dinlerin kutsal kitaplarında sığınma, misafir etme ve yabancıların korunması ile ilgili ayetler bulunmaktadır. ${ }^{2}$

Binlerce yıldan beri mevcut olan mültecilik kavramı 20. Yüzyıla kadar basit düzenlemelerle ortaya konmuştur. Dolayısıyla mülteci kavramı üzerinde fazla durulmamış

\footnotetext{
* Marmara Üniversitesi, Sosyal Bilimler Enstitüsü, Gazetecilik Anabilim Dalı Yüksek Lisans Öğrencisi.

1 Türkiye, Avrupa dışından gelenleri mülteci statüsü ile tanımlamamaktadır. Bu bakımdan Suriyeliler mülteci statüsünde değildir. Türkiye'nin kendi iç hukukuna göre oluşturduğu kategoriler yerine uluslararası hukuk ve insan haklarını dikkate alarak Suriyeliler için mülteci kavramını kullanacağım.

2 Tevfik Odman, Mülteci Hukuku (Ankara: İmaj yayınları, 1995), 5, 12.
} 
ve mültecilerin korunması sadece sosyal ve ahlaki bir sorumluluk olarak görülmüştür. ${ }^{3}$ 20. yüzyıla gelindiğinde ise büyük savaşlar, ihtilaller, bağımsızlık başkaldırılar1 ortaya çıkmış ve bunlara dayalı olarak milyonlarca kişiden oluşan göç ve iltica hareketleri meydana gelmiştir. ${ }^{4}$ Birinci Dünya Savaşı'ndan sonra kurulan Milletler Cemiyeti 1920-1930 yılları arasında Avrupadaki mülteci sorunlarına çözüm bulmak için çeşitli girişimlerde bulunmuştur. İkinci Dünya Savaşı'ndan sonra ise Birleşmiş Milletler Mülteciler Yüksek Komiserliği'nin kurulması ve 1951 tarihli Mültecilerin Hukuki Durumuna Dair Cenevre Sözleşmesi'nin imzalanması mülteci koruması açısından önemli bir evreyi oluşturmaktadır. Çünkü ilk defa mültecilerin korunması ve ihtiyaçlarının giderilmesi uluslararası hukuk kapsamında değerlendirilmiştir. ${ }^{5}$

Yabancının ağırlanmasının hem hak hem de uluslararası bir sorumluluk olarak kavranması akıllara öncelikle Kant’ı getirmektedir. Aydınlanma Çağının düşünürü Kant "Edebi Barış" adlı denemesinde misafirperverliği edebi barışın şartlarından biri olarak öne sürmüş ve ahlaki sorumluluğun ötesinde hukuki bir boyutta ele almıştır. Kant, sığınma hakkını kozmopolitik hukuk çerçevesinde ele alsa da uluslararası sözleşmelerde olduğu gibi sığınma hakkının tanınma yetkisini ulus devletlerin inisiyatifine bırakmıştır. Bu durum ulus devletin egemenlik iddiası ile insan hakları arasındaki çatışmayı doğurmaktadır. Çünkü devletler göç politikalarının uygulanmasında egemenlik haklarından ödün vermemeye özen göstermekte ve uluslararası göç hareketi egemen devletlerin özellikle güçlü devletlerin menfaatleri doğrultusunda yönlendirilmektedir. ${ }^{6}$ Arendt, bu konuya şu ifadelerle dikkat çekmiştir: "bu fikrin, hâlâ egemen devletler arasında var olan anlaşmalara ve sözleşmelere göre işleyen mevcut uluslararası hukuk alanını aştığının anlaşılması gerekir ve ulusların üstünde olan bir alan, şimdilik mevcut değildir. Ayrıca bu ikilem, bir "dünya hükümeti” nin kurulmasıyla hiçbir biçimde ortadan kalkmayacaktır." Derrida, günümüzde uluslararası hukukun, egemen devletler arasındaki anlaşmalarla sınırlandırıldığı ve bir dünya hükümetinin bile yerinden edilmişlerin meselelerini çözemeyeceği konusunda Arendt'le aynı fikirde isek misafirliği uygulayan kentler için bir umut var mıdır sorusunu sorar. ${ }^{8}$ Derrida’nın, devletten bağımsız sığınma kentlerinin kurulma olasılığından bahsetme nedeni, günümüzde hâlâ bir açmaz olarak duran göçmenlerin, vatansızların ve mültecilerin sorunlarının çözümü için misafirperverliğin devletle ilişkisinin yeniden sorgulanması ve misafirperverlik düşüncesinin hukuki ve politik olanı dönüştürme olasılığının araştırılması gerektiğ $i^{9}$ düşüncesinden ileri gelmektedir.

3 Odman, Mülteci Hukuku, 19.

41912 yılı Balkan Savaşı, 1914-1918 yılları arasındaki Birinci Dünya Savaşı, 1917 Rus ihtilali sırasında Avrupa, Asya kıtaları ve Ortadoğu’yu kapsayan coğrafya zorunlu göç olaylarına tanık olmuştur.

Odman, Mülteci Hukuku, 14.

5 Bülent Çiçekli, Yabancılar ve Mülteci Hukuku (Ankara: Seçkin Yayıncılık, 2014), 222-223.

6 Odman, Mülteci Hukuku, 20.

7 Jacques Derrida, Bağışlama ve Kozmopolitizm, çev., Ali Utku-Mukadder Erkan (İstanbul: Birey yayıncılık, 2005), 22.

8 Derrida, Bağışlama ve Kozmopolitizm, 22-23.

9 Zeynep Direk, Başkalık Deneyimi: Kıta Avrupası Felsefesi Üzerine Denemeler (İstanbul: Yapı Kredi Yayınları, $2005), 186$. 
Sanayileşmiş ve gelişme yolundaki birçok ülke 1951 Sözleşmesi’nde ve mültecilerle ilgili diğer belgelerde yer alan temel ilkelerden bazılarına karşı koymakta ya da doğrudan çiğnemektedir. ${ }^{10}$ Uluslararası ve bölgesel nitelikli mülteci hukuku, ülkelerin gözlemesi gereken ilke ve standartları ortaya koymaktadır; ancak hukuk kuralları, özellikle mülteci düşmanlığının arttığı bir dönemde, tek başına koruma sağlamamaktadır. ${ }^{11}$ Özellikle Avrupa Birliği ülkelerinin uygulamalarında bu durum sık gözlenmektedir. Schengen yasalarının bir sonucu olarak Avrupa Birliği ülkelerinde iç sınırlar kaldırılırken dış sınırlar sıkı bir şekilde kapatılmaktadır. Sığınma talepleri eskiden olduğundan daha çok reddedilmektedir. Açık ve makul hukuki bir yanıt biçiminde bunu yapmadıklarında yasanın zorla uygulanması polis teşkilatına bırakılmaktadır. ${ }^{12}$ Bugün İkinci Dünya Savaşı’ndan sonra küresel çapta yerinden edilenlerin sayısının ilk kez 50 milyonun üzerine çıkmas ${ }^{13}$ ve Suriye'den gelen kitlesel mülteci hareketine yönelik tepkinin devletler arasında bir pazarlığa dönüşmesi kısaca yabancının ağırlanmasına yönelik "misafirsevmez" politikaların uygulanması bizi Derrida’nın misafirperverlik kavramını yeniden tartışma davetine yönlendirmektedir.

$\mathrm{Bu}$ yazıda misafirperverlik kavramının ne olduğu, sınırları ve mümkünlülüğü üzerinde durularak Suriyeli mültecilere yönelik misafir söylemi irdelenecektir. Misafirperverlik kavramı Kant'ın misafirperverlik hukuku düşüncesi ile Derrida’nın Levinas'tan esinlenerek oluşturduğu misafirperverlik etiği düşüncesi bağlamında ortaya koyulacak. Yasalara ve devlete bağlı Kantçı misafirperverlik düşüncesinin Mültecilere İlişkin Uluslararası Sözleşmelere yansıması ve sınırları üzerinde durulduktan sonra bu sınırların aşılmasının olanağını tartışmak için Derrida’nın etik misafirperverlik düşüncesi incelenecektir. Son olarak Türkiye’nin Suriyeli mültecilere yönelik yasa ve uygulamalarında mültecilerin ağarlanmasında ortaya konan sınırlar ve geçicilik üzerinde durulacak. Aynı zamanda toplumsal kamuoyu araştırmalarının ortaya koyduğu toplum algısında ve gazetelere yansıyan bazı haberlerde Suriyeli mültecilere yönelik misafirlik söyleminin yarattığ verlik düşüncesi açısından irdelenecektir.

\section{Misafirperverlik Hukuku (Koşullu)}

"Dünya vatandaşlı̆̆ı hukuku, evrensel bir misafirlik şartları ile sınırlandırılmalıdır."14

Kant'ın Edebi Barış Denemesini yazmasını etkileyen tarihsel olayların başında 1795'te Fransa ile Prusya arasında imzalanan Basel Antlaşması gelir. Basel Barış Antlaşması Kant’a göre gerçek bir barış değildir. Çünkü savaşa neden olabilecek hükümler barındırmaktadır. ${ }^{15}$ Kant, sürekli bir barışın ilkelerini ortaya koymak için kaleme

10 BMMYK, Dünya Mültecilerinin Durumu: Bir İnsanlık Sorunu (Ankara: Numune Matbaas1, 1997), 62.

11 BMMYK, Dünya Mültecilerin Durumu, 81.

12 Derrida, Bağışlama ve Kozmopolitizm, 26.

13 “UNHCR Global Trends Report” son güncelleme 11 Temmuz, 2016, http://www.unhcr.org/trends2013/.

14 Immanuel Kant, Edebi Barış Üzerine Felsefi Deneme, çev., Yavuz Abadan ve Seha L. Meray (Ankara: Ajans Türk Matbaası, 1960), 26.

15 Kaan Harun Ökten, “Immanuel Kant’ın Edebi Barış Üzerine Felsefi Deneme Adlı Eseriyle Ortaya Koyduğu Edebi Barış Fikri Ve Bu Fikrin Uluslararası İlişkiler Düşüncesinde Yarattığı Etki” (Doktora Tezi, İstanbul Üniversitesi, 2001), 78-79. 
aldığı bu denemesinde savaş, dünya vatandaşlığı (kozmopolitizm) ve evrensel misafirperverlik kavramları üzerinde durmuştur.

Kant, denemesinde barış için nihai olan üç maddeden bahsetmektedir. İlk maddesi "her devletin esas teşkilatı cumhuriyetçi olmalıdır", ikinci maddesi "devletler hukuku hür devletlerden kurulu bir federasyona dayanmalıdır", üçüncü maddesi ise "Dünya vatandaşlığı hukuku evrensel bir misafirperverlik şartları ile sınırlandırılmalıdır." 16

Kant evrensel misafirlik kavramını şöyle açıklamıştır:

"Daha önceki maddelerde olduğu gibi, burada insanseverlik değil, fakat bir hak söz konusudur ve konukluk (Wirtbarkeit), bir yabancının bir başkasının toprağına varışında, ondan düşman muamelesi görmeme hakkıdır. O kimse, eğer mahvı anlamına gelmeyecekse yabancıyı geri gönderebilir; ama yabancıya, yerinde barışçıl olarak durduğu sürece, düşmanca davranamaz. Yabancının isteyebileceği bir kalma hakkı (Gastrecht) değildir (bu ancak onu bir süre için ev halkından biri haline getirecek bir sözleşme ile olabilirdi), fakat bir ziyaret hakkıdır; bu da yeryüzünün ortak mülkiyet hakkı nedeniyle bütün insanlara ait olan kendini topluma sunma hakkıdır; çünkü yeryüzü yuvarlak olduğu için insanlar sonsuz olarak dağılamazlar, birbirlerine tahammül etmek zorundadırlar, fakat kaynağına bakılırsa, hiç kimse yeryüzündeki bir yer üzerinde başkasına göre daha fazla hak sahibi değildir." ${ }^{17}$

Kant’n misafirperverliği iyilikseverlik değil bir hak olarak vurgulaması bu hakkın insanlık dışı veya insanlarla ilgisiz olduğunu değil, fakat hukuk olarak misafirperverlik hakkının dürtü anlamındaki insan sevgisiyle ilgili olmadığını göstermektedir. Kant'ın misafirperverliği yasa tarafından düzenlenmiş bir zorunluluk, hukuk ile ilgilidir. $^{18}$

Derrida, "Kozmopolit hukuk genel konukluğun koşullarıyla sınırlandırılmalıdır" ifadesinde Kant'ın "kozmopolit hukuk" ve "konukluk" sözcüklerinin altını çizdiğini belirtir. Dolayısıyla Kant'ın misafirperverlik kavramı ahlak ve politikanın değil, hukukun, yurttaşlığın, devletin yurttaşıyla kurduğu ilişkiyle belirlenen bir alandan oluşur. Bu alan uluslararası anlaşmalar ve bir tür öngörülmüş Birleşmiş Milletler yasalarının oluşturduğu koşullardan oluşmaktadır. Bununla birlikte Derrida, Kant’ın bu ifadesi ile daha en başta bir koşulluk sorusu veya koşulsuz misafirperverlik sorusunun ortaya çıktığını belirtir. ${ }^{19}$ Derrida, yabancıya koşul öne sürülmeden ve sorgusuzca buyur edilmesini mutlak misafirperverlik olarak tanımlamaktadır. Derrida’ya göre Kant'in evrensel misafirperverlik kavramını bir zorunluluk, bir hak olarak tanımlaması misafirperverliği sınırlı kılmaktadır; bundan dolayı mutlak misafirperverlikten bahsedilemez. Bu bakımdan Derrida, Kant’ın misafirperverlik düşüncesini koşullu misafirperverlik olarak adlandırmaktadır. ${ }^{20}$

16 Kant, Edebi Barıș Üzerine Felsefi Deneme, 18, 22 ,26.

17 Jacques Derrida, Konuksev (-er-/-mez-) lik Pera Peras Poros: Jacgues Derrida ile Birlikte Disiplinlerarası Çalışma İçinde, haz., Önay Sözer, Ferda Keskin (İstanbul: Türkiye İş Bankası Yayınları, 2012), 11.

18 Jacques Derrida, Konuksev (-er-/-mez-) lik, 9.

19 Jacques Derrida, Konuksev (-er-/-mez-) lik 7-8.

20 S. Gizem Alpakgir Cevheri, "Mültecilik kavramının ve Mültecilerin Hukuki Durumuna Dair Sözleşmede Yer Alan Hakların Koşullu Misafirperverlik Üzerinden Değerlendirilmesi” ( III. Türkiye Lisansüstü Çalışmalar Kongresi Bildiriler Kitabı- III, Sakarya Üniversitesi, Sakarya, Mayıs 15-18, 2014). 
Kant evrensel misafirperverliği koşullandırırken yeryüzünün yuvarlaklığına göndermede bulunur. Kant’a göre evrensel misafirperverlik koşullu olmak zorundadır, çünkü yeryüzünün yuvarlaklığı sınırsız dağılımı imkânsız kılmaktadır. Bundan dolayı insanlar eninde sonunda bir arada yaşamayı hoş görmek zorundadır. Her gelen koşulsuz kabul edilemeyeceğinden devletlerin ve kurumların varlığg gereklidir. ${ }^{21}$

Kant'in söz konusu gerekçeye dayanarak oluşturduğu misafirperverlik düşüncesi ikamet hakkı yerine sadece ziyaret hakkını içermektedir. Yani Kant'a göre misafirlik ziyaret (geçici ikamet) hakkından ibarettir. Sürekli misafir olma hakkının ise özel bir anlaşma yoluyla verilmesinden bahsetmekte, bunu "yararlılık anlaşması" olarak adlandırmaktadır. ${ }^{22}$ Diğer bir deyişle geçici ikamet bir hak iken, sürekli ikamet bir imtiyazdir. $^{23}$

Kant geçici ikamet hakkını oluştururken iki farklı önermeye başvurmaktadır. İlk önerme "tüm insanların birleşme kapasitesi" diğer önerme ise "dünya yüzeyinin ortak mülkiyeti” ne dayanmaktadır. Dünya yüzeyinin ortak mülkiyeti ilkesinden yola çıkan Kant, yabancıların belli bir toprağın kaynağından yararlanma isteğinin barışçıl olduğu ve yerli halkın yaşamlarını tehlikeye sokmadığı sürece geri çevrilmesinin adil olmadığını öne sürmüştür. Kant, ortak mülkiyet yargısının Batılı sömürgecilik için bir yasal dayanak olarak kullanılmasından kaçınmış, aynı zamanda dünya yüzeyinin sınırlı olmasından dolayı mevcut kaynakların diğer insanlarla birlikte kullanılması için insanların kamusal bir birleşme içine girme hakkını temellendirmiştir. Kısaca Kant Aydınlanmacı düşünüşle mesafeleri kısaltmak, insanları biraya getirmek için bu önermeleri ortaya atmıştır. Çünkü Kant’a göre kişinin diğerleriyle sivil birleşme hakkı temel insan hakkıdır. ${ }^{24}$

Bunun yanında Kant geçici ikamet hakkının reddedilmesinin mümkün olmadığından da bahsetmiştir. Eğer sığınma talebinde bulunan kişinin hayati tehlikesi varsa bu talep reddedilemez. Burada Kant misafirperverlik hakkını ahlaki yükümlülük olarak tanımlayıp bırakmamıştır, bir hak olarak ele alması savaş mağdurlarına, mültecilere ve vatansızlara karşı insanlık dışı tutumun ortadan kaldırılması için hukuksal bir zemin sağlamıştır. ${ }^{25}$ Kant’’n sığınma hakkını hukuki bir zemine oturtması bazı açılardan yetersiz kalmıştır. Çünkü sığınma hakkı devletin yükümlülüğüne bırakılmasının yanında bir devletin vatandaşı olmayı da gerektirmektedir. Dolaysıyla Kant kozmopolit hakkı her ne kadar yabancıların hakkı olarak görse de buradaki yabancı kavramı belirsiz durmaktadır. Yabancı kavramı dünya yurttaşı anlamında kullanılmamış-

21 Direk, Başkalık Deneyimi: Kıta Avrupası Felsefesi Üzerine Denemeler, 193.

22 Yararlılık anlaşması, cumhuriyete dayalı hükümranın uzun vadeli ticari anlaşmalarda bulunan, belli işlevleri yerine getiren, kendi politik makamını temsil eden yabancılara tanıdığı özel bir imtiyazdır. Bu durumun tarihsel örnekleri olarak Devrim öncesinde Fransa'da yabancılara özel ikamet ve mülk sahibi olma hakkının tanınması veya 18. Yüzyıldan itibaren Osmanlı'nın, Çin'in ,Japonya'nın ve Hindistan'ın Batılılara verdikleri ticari imtiyazlar gösterilebilir.

Seyla Behabib, Ötekilerin Hakları Yabancılar, Yerliler, Vatandaşlar, çev., Berna Akkıyal (İstanbul: İletişim Yayınlar1, 2014), 38.

23 Benhabib, Ötekilerin Haklarl, 48.

24 Benhabib, Ötekilerin Hakları, 40,47.

25 Özlem Duva, "Evrensel Konukseverlik ve Haklara Sahip Olma Hakkı" (Birinci Uluslararası Felsefe Kongresi: Eşitlik, Özgürlük ve Kardeşlik Bildirileri, Uludağ Üniversitesi Fen Edebiyat Fakültesi, Bursa, 14-16 Ekim, 2010). 
tır, daha çok gönüllü bir yabancı kastedilmektedir. Bu açıdan istemsiz bir yabancılık olarak sığınma hakkı gerçek bir hak olarak görülmemiş, kabulü koşullandırılmıştır. ${ }^{26}$

Kant'ın yabancının karşılanması konusunu kişisel olmayan, soyut bir ilişki biçimine indirgemesi misafirin "bizim" toprağımızda karşılanmasına olanak tanır; ancak bu karşılama ev sahibi ile misafir arasında bir ilişki kurulmasına imkân tanımaz. Yabancıya sadece yasal bir hak sunulmuş olur. Öteki gittiği yeni yurtta evin, ulusun ve kültürün düzeni ve kurallarına saygı duyması ve o yurdun dilini öğrenmesi koşuluyla hoş karşılanabilir. Bu bakımdan efendi efendi olarak kalır, misafir ise davetli misafirdir. ${ }^{27}$

Koşullu misafirperverlikte ev sahibinin efendi olarak kalmasını Derrida şöyle ifade etmektedir: "Konukluk elbette bir hak, bir ödev, bir zorunluluk, bir yasadır, yabanc1 ötekinin dost olarak ağırlanmasıdır, öyle olması gerekir; ancak bunun koşulu ev sahibinin, host'un, Wirt' in kabul eden veya barındıran ya da iltica hakkı verenin patron, evin efendisi olarak kalması, kendi evinde kendi otoritesini koruması, kendini koruması, kendine bakana bakması ve onu koruması dolayısıyla konukluk yasasını evin, oikonomia'nin yasası, kendi evinin yasası, yerin (ev, hotel, hastane, yurt, aile, kent, ulus, dil) yasası olarak, sunulan konukseverliğin kendisinin yerinin sınırlarını çizen ve onun üzerinde otoritesini koruyan, otoritenin doğruluğunu koruyan, korumanın yanı doğruluğun yeri olarak kalan ve dolayısıyla sunulan armağanı sınırlayan ve bu sınırlamayı, yani kendi evinde kendi- olmayl, ödülün ve konukseverliğin koşulu yapan özdeşlik yasası olarak olumlamasıdır."28

Kant'ın misafirperverlik düşüncesinde mülteciler, vatansızlar sığındıkları ülkenin toprağına "geçici" olarak girebilme hakkına sahiptir ve mültecilerin ülke sınırından geçtikten sonraki durumları da belirsizliğini korumaktadır. Çünkü Kant’ın misafirperverlik düşüncesinde beklenmedik ziyarete yer yoktur, bundan dolayı ötekiyle bir ilişkiden de bahsedilemez. Ötekiyle ilişkinin yok sayıldığı bu durumda mülteciler ancak sığındığı ülkenin kurallarına uyum gösterdiği müddetçe anlayışla karşılanabilmektedir. Kant'ın bize muğlak bir miras bıraktığına değinen Seyla Benhabib, misafirperverlik bekleyenlerin kovulmasını engelleyecek tek güvencenin onların yok oluşlarına bağlı olması ve ötekilerin yoğun ihtiyaçlarının mevcut egemen toplulukların iradesinin razı edilmesi için yeterli bir zemin oluşturmaması Kant'ın Kozmopolit hak düşüncesi açısından eksik kaldığını belirtir. ${ }^{29}$

\section{Misafirperverlik Etiği (Koşulsuz)}

Derrida’nın sorgusuz sualsiz kapıları herkese açmaktan bahsettiği koşulsuz misafirperverlik düşüncesi Emmanuel Levinas’in misafirperverlik etiği düşüncesine dayanmaktadır.

26 Serpil Tunç, “Konukseverlik: Hukukta ve Hukukun Ötesinde” (Birinci Uluslararası Felsefe Kongresi: Eşitlik, Özgürlük ve Kardeşlik Bildirileri, Uludağ Üniversitesi Fen Edebiyat Fakültesi, Bursa, 14-16 Ekim, 2010).

27 Meyda Yeğenoğlu, Avrupa'da İslam, Göçmenlik ve Konukseverlik (İstanbul: İstanbul Bilgi Üniversitesi Yayınları, 2016), 10.

28 Derrida, "Konuksev (-er-/-mez-) lik, 10.

29 Benhabib, Ötekilerin Haklart: Yabancılar, 41-42. 
Kant, misafirperverliği yasa olarak dolayısıyla misafirperverliğin koşulları ve sınırlarıyla ele alırken, Levinas ise misafirperverliği bizzat etiklik sorusunun kendisi olarak ele almıştır. ${ }^{30}$ Derrida, Kant ve Levinas'ı birlikte düşünerek etik misafirperverliğin sınırlarını deneyimlemeye çalışmış ve bizi misafirperverliği yeniden düşünmeye davet etmiştir. Açıkçası Derrida’nın sorusu Levinas’ın misafirperverlik etiğinin “toplum, ulus, Devlet veya Ulus-Devlet dâhilinde, ailevi meskenin ötesinde bir yasa ve siyaset" için uygulanabilir olup olmadığıdır. ${ }^{31}$ Derrida’nın söz konusu sorgulamasına geçmeden önce Levinas'ın etik düşüncesini inceleyelim.

Levinas'ın etiği sorumluluk etiğidir. Fakat Levinas'in sorumluluğu geleneksel anlamda tanımlanan kişisel sorumluluktan farklıdır. Kişinin sözleri ve eylemlerinden sorumlu tutulduğu geleneksel sorumluluktan ayrı olarak Levinas'in sorumluluk anlayışında bir kişinin "ben” diyebilmesinin koşulu öteki için duyduğu sorumluluğa bağlıdır. ${ }^{32}$ Dolayısıyla Levinas, ben'in karşısına öteki'yi konumlandırmamış aksine özne’nin kendini kurmasını öteki’ye karşı duyduğu sorumluluğa bağlı kılmıştır.

Gerçeklikten veya öznellikten yola çıkan geleneksel felsefenin aksine Levinas ötekiden başlar. Levinas'ın merkeze aldığı öteki, farklı olanı aynıya indirgeyen ve ötekinin başkalığını yıkan indirgemeci geleneksel felsefeden bambaşka bir yöndedir. Levinas için öteki kavranamaz, bilinemez; çünkü öteki sınırsız ve indirgenemez başkalıktır. ${ }^{33}$

Ötekiyle ilişkiyi sonsuz bir sorumlulukla kuran Levinas’a göre misafirperverlik “yüze (visage) kendini açmanın, daha açık söylersek yüzü "ağırlama”nın adıdır." ${ }^{34}$ Levinas'ın yüz kavramı ile kastettiği beden veya bir biçim değildir. Levinas şöyle ifade eder: "yüzle ilişki, aynı zamanda tamamıyla zayıf olanla, tümüyle sergilenmiş, çıplak ve soyunmuş olanla ilişkidir, soyunma ve bunun sonucunda da yalnız olanla ve ölüm diye adlandırılan en derin yalnızlığa uğrayabilecek olanla ilişkidir; dolayısıyla sonuçta Ötekinin Yüzünde daima Ötekinin ölümü vardır ve böylece bir biçimde, cinayete kışkırtma, sonuna dek gitmeye, ötekini tümden göz ardı etmeye eğilim vardır, aynı zamanda Yüz, işte çelişkili olan da bu, “Öldürmeyeceksin”dir. Öl-dür-me-ye-cek-sin daha da açılabilir; bu ötekini tek başına ölüme bırakamayacağının olgusudur." ${ }^{35}$ Görüldüğü gibi yüz ile kastedilen öteki için duyulması gereken sorumluluğa davettir.

Öteki ile ilişkideki sorumluluk hiçbir zaman tamamlanamayan bir sorumluluktur. Bu bağlamda Levinas’ın koşulsuz sorumluluk fikri ev sahibi ile misafir ilişkisini tersine çeviren koşulsuz misafirperverlik deneyimi ortaya çıkarır. ${ }^{36}$ Bu koşulsuz misa-

\footnotetext{
30 Yeğenoğlu, Avrupa'da İslam, 64.

31 Yeğenoğlu, Avrupa'da İslam, 64.

32 Elif çırakman, “Levinas’ta Öteki ve Adalet: Eleştirel Bir Not”, Doğu Batı Düşünce Dergisi 13/4 (2000-01): 180. 33 Sibel Kibar, “Levinas'ta Adaletin Terazisi Yok!", MonoKL Levinas Özel Sayısı VIII/IX (2010): 443.

34 Jacques Derrida, “Ağırlama Sözcüğ̈̈, MonoKL Levinas Özel Sayısı VIII/IX (2010): 562.

35 Emmanel Levinas, Sonsuza Tanıklı: Emmanuel Levinas'tan Seçme Yazılar, haz., Zeynep Direk ve Erdem Gökyaran (İstanbul: Metis Yayınları, 2010), 242-243.

36 Ahmet Cüneyt Gültekin, "Bağışlanan konukseverlik ve Konuksever Bağışlama: Derrida Felsefesinde Etik (Olanaksız) ve Politika (Olanaklı) İlişkisi” Felsefe ve Sosyal Bilimler Dergisi, 17 (2014 Bahar), 20. (erişim 21.08.2016)
} 
firperverlik deneyimi, Levinas’a göre yabancıyı evinde ağırlamakla mülksüzleşmeyi tecrübe etmek ve kendini kökünden sökülmüş olarak bulmaktır. ${ }^{37}$

Ötekine karşı sonsuz sorumluluk ve misafirperverlik fikrinden dolayı etik misafirperverlik bir yasaya dönüştürülememektedir. Meyda Yeğenoğlu’nun belirttiği gibi Levinas'in etik konukseverliğinin tematize edilebilen bir siyasete indirgenemezliği, Levinas'ın misafirperverlik tezlerinin günümüzün en acil meselelerinden birini yani yersiz yurtsuz insanlar, sürgündekiler, mülteciler ve göçmenler bağlamında tartışılmasının uygun olmadiğ 1 anlamına gelmez. ${ }^{38}$

Levinas’ın misafirperverlik tezlerini bu bağlamda tartışmaya açan Derrida, “yabancının, evraklı ya da evraksız göçmenin, sürgünün, sığınma hakkı talep edenin, ülkesiz ya da devletsiz kalmışların, zorunlu göçe tabi tutulmuşların” şiddet ve sıkıntı yaşadığı şimdiki zamanı tarif ederken misafirperverliğin yeniden düşünülmesi gerektiğine işaret eder. ${ }^{39} \mathrm{Bu}$ doğrultuda yapıbozumcu bir okuma yapan Derrida, Latince kökenli hospitalitat (misafirperverlik) kelimesini sorunlu bir sözcük olarak niteler. Kendi çelişkisini kendisinde taşıyan bu sözcüğün misafirsevmezliği (hostitilite) kendisinde parazit olarak taşıdığını ifade eder. ${ }^{40}$ Düşmanlık (hostility) ve misafirperverlik(hospitality) kelimelerinin aynı latince kök hos tan gelmesi host kelimesinin hem misafirperverlik gösteren kimseyi hem de istilacıyı adlandırmada kullanılabilmesi ${ }^{41}$ bu sözcügün çelişkili yapısını göstermektedir.

Derrida, misafirperverlik düşüncesinin sınırlarını ve bu sınırların nasıl yer değiştirdiğini yani bu düşüncenin aporetik yapısını göstermeyi hedeflemektedir. ${ }^{42} \mathrm{Bu}$ doğrultuda Derrida, "Konukluk yasasında bir kendini sınırlama, bir kendiyle çelişme aksiyomu var. Efendiliğin ve kendi evinde olmanın yeniden evetlenmesi olarak, konukseverlik kendini eşikle sınırlar, daima kendisinin eşiğinde kalır, eşiğe buyurur ve tam da bu ölçüde geçilmesine izin verir, göründüğü eşiğin geçilmesini bir ölçüde yasaklar. Konukseverlik eşik olur. Bunun için onun ne olduğunu bilmiyoruz, bilemiyoruz. Onu bildiğimiz anda artık bilmiyoruz; tam olarak nedir, eşikteki kimliği nedir, bilmiyoruz"43 İfadesiyle misafirperverliğin sınır ve çelişkisini göstermektedir. Cümledeki "bilmiyoruz" vurgusu misafirperverliğin nesnel bir bilgiye uyan bir kavram olmadığını göstermektedir. ${ }^{44}$

Derrida için koşulsuz ideal ile gerçekliğin koşulları arasındaki karşıtlıkta bir çağrı ve meydan okuma vardır. Bu çağrı, koşulsuzluğun göz önünde bulundurularak yasaların daha nasıl misafirperver yapılabileceğiyle ilgili politik bir yapısöküm pratiği olarak görülebilir. Yapısöküm "gelecek olan”a misafirperver olma çağrısında bulunur. Böylece misafirperverliğin ne olduğunu bilmiyoruz cümlesi misafirliğin gelecek ola-

37 Robert Bernasconi, Levinas Okumaları, çev., Zeynep Direk (İstanbul: Pinhan, 2011), 113.

38 Yeğenoğlu, Avrupa'da İslam, 12.

39 Direk, Başkalık Deneyimi, 186.

40 Derrida, "Konuksev (-er-/-mez-) lik, 8.

41 Richard Kearney, Yabancılar, Tanrılar ve Canavarlar: Ötekiliği Yorumlamak, çev.,Barış Özkul (İstanbul: Metis Yayınlar1, 2012), 90-91.

42 Gültekin, "Bağışlanan Konukseverlik", 14

43 Derrida, "Konuksev (-er-/-mez-) lik, 28.

44 Derrida, "Konuksev (-er-/-mez-) lik, 16. 
na dair olduğunu da göstermektedir. "Daha değil”; gelecek olan ve kendisini burada sunmayan bir misafirperverliğe ilişkindir. ${ }^{45}$

Derrida koşulsuz konukseverliği şöyle tanımlamıştır: "saf konukseverlik arrivant'ı yani gelen kişiyi, hiçbir koşul öne sürmeden, hakkında adı dâhil kim olduğuna dair hiçbir şey bilmeden veya bir kimlik belgesi sormadan buyur etmeye dayanır." ${ }^{46} \mathrm{O}$ hâlde koşullu ile koşulsuz misafirperverliğin farkı ortaya konabilir. Koşullu misafirperverlik bir "davet” olarak düşünülürse, koşulsuz misafirperverlik ise öngörülemeyen bir ziyaret olarak düşünülebilir. ${ }^{47}$

Beklenmeyen ziyarette benin kesintiye uğramasından söz edilebilir. Burada Levinas'in misafirin rehinesi olma terimine göndermede bulunabilir. Bu durumda davet eden ile davet edilen arasında yer değişimi söz konusudur. Böylece ev sahibi artık rehinedir. Sorumluluk almaktan söz edebileceğimiz bu misafirperverlikte benlik ideolojisinin yıkımından bahsedebiliriz. ${ }^{48}$

Koşulsuz misafirperverlikte özneyle birlikte mülkiyet ilişkisi de kesintiye uğrar. Koşulsuz misafirperverlik mülkiyetten önce gelir; çünkü koşulsuz olması için ev mülkiyet olmaktan çıkarılmalı, böylece evin efendisinin hâkimiyeti son bulmalıdır.

Michel Naas koşulsuz misafirperverlik, "herhangi bir bilgi ve tanışıklıktan önce ötekine koşulsuz bir açılmaya dayanıyorsa, evimize veya ülkemize buyur ettiğimiz kişinin dost mu düşman mı olduğunu, bize faydasının mı dokunacağı yoksa zarar mı vereceğini, yardım mı yıkım mı getireceğini asla bilemeyiz hatta bilmemeliyiz" ${ }^{49}$ ifadesinde bulunarak Derrida’nın bizi bir riskle karşı karşıya bıraktığını belirtir. Derrida riskin oluşumunu mesihçi bir tarzda düşünmüştür. Çünkü gelen kurtarabilir veya beter hale sokabilir. İşte bu noktada radikal deneyim söz konusudur. ${ }^{50}$ Derrida deneyim ve yeniliğe önem vermektedir. Her misafirperverlik deneyiminin yeni bir dil icat etmesi gerektiğini belirtir. ${ }^{51}$ Derrida tekilliği, yabancılığ ve başkalığı, yani hesap edilemez olanı hesaba katmaya çalışmıştır. ${ }^{52}$

Derrida, Uluslararası Yazarlar Parlamentosu'nda dünyanın her yerinde bir tür sığınma kentlerinin açılmasını talep ettiklerini belirtmektedir. Her bir sığınma kentlerinin ötekinden ve devletten bağımsız, ancak dayanışma içinde, özerk bir yapıda kurulmasından bahsetmektedir. ${ }^{53}$ Fransa'da ve Avrupa’da sığınma talebinin reddedilme say1sının artması ve sığınma talebinde bulunanların sayılarının gittikçe artmasını göz önünde bulunduran Derrida bu tür şeyin zorunlu bir görev olduğunu hatırlatmaktadır. ${ }^{54}$ Fakat sığınma kentleri Derrida’nın koşulsuz misafirperverlik düşüncesinin pratik bir uygulaması değildir. ${ }^{55}$ Çünkü etik misafirperverlik (koşulsuz) sonsuz bir

45 Gültekin, "Bağışlanan Konukseverlik", 23.

46 Michel Naas, “Alors, qui êtes-vous? Jacgues Derrida ve Konukseverlik Sorusu”, Cogito 47-48 (2006): 239.

47 Direk, Başkalık Deneyimi, 212.

48 Tunç "Konukseverlik: Hukukta ve Hukukun Ötesinde".

49 Naas, "Alors, qui êtes-vous?", 246.

50 Direk, Başkalık Deneyimi, 212.

51 Naas, "Alors, qui êtes-vous?", 240.

52 Direk, Başkalık Deneyimi, 186.

53 Derrida, Bağışlama ve Kozmopolitizm, 18.

54 Derrida, Bağışlama ve Kozmopolitizm, 22.

55 Tunç, "Konukseverlik: Hukukta ve Hukukun Ötesinde”. 
sorumlulukla yüklü ve adalet gibi imkânsızdır. Ancak bu imkânsızlık bir misafirperverlik politikasını da imkânsızlaştırmaz. Adalet nosyonun hukukun yapısökümüne imkân verdiği gibi koşulsuz misafirperverlikte, koşullu misafirperverliğin yapısökümüne imkân verir. ${ }^{56}$ Derrida adaletin içinde bir açmazın yattığını belirtir, dolayısıyla adalet imkânsızdır. Adaleti sağlayabilmek için yasa yapısöküme uğratılmalı ve iyileştirilmelidir; ancak yasa asla adil değildir. Derrida adalet ve yasanın birbirinden ayrılamaz olduğunu vurgular. İkisi arasındaki ilişki indirgenemezdir. Aynı şekilde koşulsuz misafirperverlik de imkânsızdır. Yasalar tam anlamıyla koşulsuz misafirperverliği sağlayamayacaktır. İkisi arasındaki ilişki indirgenemez kalacaktır. Yasa geliştirilebilir ve yasa üzerinde yapılan değişikliklerle misafirperverliğin koşulları iyileştirilebilir. ${ }^{57}$ Kısaca koşullu misafirperverliğin ideal bir hale getirilmesi ve iyileştirilmesi için koşulsuz misafirperverliğin daima arzulanması ve ona ulaşılmaya çalışılması gerekir. ${ }^{58}$ Sonuç olarak koşulsuz misafirperverlik hukuk ve politika da uygulamaya geçirilecek hazır bir projeden çok yasalara esin kaynağı olabilecek ve "gelecek" olana dairdir.

\section{Mültecilere Dair Uluslararası Sözleşmeler ve Koşullu Misafirperverlik}

Dünya vatandaşlığı hakkı genel misafirperverlik şartları çerçevesinde ele alınırken uluslararası hukukun esas aktörleri olarak birey yerine devletler kabul edilmiştir. Tek bir siyasi merkeze sahip olan dünya cumhuriyeti yerine, egemen ve bağımsız devletlerden oluşan milletler birliği günümüzdeki adıyla Birlemiş Milletler düşüncesi benimsenmiştir. Kant barışı bir dünya devletinin değil, cumhuriyetçi devletleri içeren bir yapının oluşturacağını düşünmüştür. ${ }^{59}$ Görüldüğü üzere bugünkü Birleşmiş Milletler yapısının kökenleri Kant'ın düşüncelerine dayanmaktadır. Kant’ın geçici ikamet kavramının izleri Birleşmiş Milletler öncülüğünde yürütülen uluslararası mülteci sözleşmelerinde ve yasalarında yer almaktadır.

Uluslararası mülteci hukukunun temelini BM öncülügünde yürütülen 1951 tarihli "Mültecilerin Hukuki Statüsüne Dair Sözleşme”(Cenevre Sözleşmesi) ile 1967 tarihli "Mültecilerin Hukuki Statüsüne İlişkin Protokol" oluşturmaktadır. ${ }^{60}$ Sığınma hakkının temel bir hak olduğuna dair herhangi bir ibareye sahip olmayan 1951 Cenevre Sözleşmesi devletleri bir yükümlülük altına sokmamakta; ancak iltica hakkının tanınmasından sonra uyulması gereken maddelere yer vermektedir. ${ }^{61}$ Aynı zamanda coğrafi ve tarihi açıdan sınırlamalar da bulunmaktadır. Fakat en önemli özelliği mülteci kavramının uluslararası hukuk bakımından bağlayıcı bir tanıma sahip olmasıdir. ${ }^{62}$

56 Yeğenoğlu, Avrupa'da İslam, 17.

57 Yeğenoğlu, Avrupa'da İslam, 66- 67-68.

58 Yeğenoğlu, Avrupa'da İslam, 17.

59 Saim Şallı, "Kant’’n Kozmopolitizm Teorisi ve Çağdaş Kozmopolitizm Akımı Üzerindeki Etkisi” (Doktora Tezi, Gazi Üniversitesi, 2011), 145.

60 Çiçekli, Yabancılar ve Mülteci Hukuku, 227.

61 Bülent Peker ve Mithat Sancar, Mülteciler ve İltica Hakkı: Yaşamın Kiyısındakilere Hoşgeldin Diyebilmek, (Ankara: İnsan Hakları Derneği Yayınları, 2001), 8.

62 Zerrin Savaşan, "AB’de Sığınma Hakkı: Ortak Sığınma Sistemi Oluşturma Amacı ve Devam Eden Kısıtlamalar", TODAİE İnsan Hakları Yilly̆̆ı, 27: 13-34 (2009), 15-16 (erişim 27.10.2016). 
Cenevre Sözleşmesi’ne göre mülteci tanımı: “1rkı, dini, tabiiyeti, belli bir toplumsal gruba mensubiyeti ve siyasi düşünceleri yüzünden, zulme uğrayacağından haklı sebeplerle korktuğu için vatandaş olduğu ülkenin dışında bulunan ve bu ülkenin korumasından yararlanamayan, ya da söz konusu korku nedeniyle, yararlanmak istemeyen; yahut tabiiyeti yoksa ve bu tür olaylar sonucu önceden yaşadığı ikamet ülkesinin dişında bulunan, oraya dönemeyen veya söz konusu korku nedeniyle dönmek istemeyen her şahsa uygulanacaktır." ${ }^{3}$

Ancak bu tanımlamada "haklı korku", "zülüm” ve " belirli bir toplumsal gruba mensubiyet” ayrıntıları yaşamları ve özgürlükleri tehdit altında, ülkeleri dışında kalmak isteyen mültecileri tanımlamak konusunda eksik kalmıştır. ${ }^{64}$ Mülteci statüsü; ırk, din, milliyet, özel bir sosyal gruba mensubiyet veya politik düşünceye sahip olma koşullarına bağlanmıştır. Baskı ve zülüm altında olmak ön koşul kabul edilmiş, baskı ve zülüm haklı bir nedene dayandırılarak açıklama zorunluluğu getirilmiştir. Özellikle geri kalmış ülkelerde kıtlık, doğal afetler ve iç çatışmalar yüzünden ortaya çıkan mülteci hareketlerine yanıt verememiştir. Böylece dar kapsamlı bu tanımlamayla uygulamada yaşanan gerçeklerle Sözleşmede yer alan hükümleri bağdaştırmak mümkün olmamıştır. ${ }^{65}$ Daha sonra oluşturulan bölgesel nitelikli mülteci sözleşmeleri daha kapsamlı mülteci tanımına yer vermiştir. Söz konusu sözleşmeler Afrika Birliği Örgütü’nün 1969 tarihli sözleşmesi ve Latin Amerika Devletlerinin 1984'te benimsediği Cartagena Deklarasyonu'dur. ${ }^{66}$

Kant’n sığınma hakkı isteyenlerin talebinin reddedilmesi eğer yok oluşlarına, çöküşlerine yol açacaksa reddedilmesinin imkânsızlığına dair iddiası Cenevre Sözleşmesi'nde yer almıştır. Sözleşmede yer alan geri göndermeme ilkesi 33. maddede şu şekildedir: "Hiçbir taraf devlet, bir mülteciyi ırkı, dini, tâbiyeti, belli bir sosyal gruba mensubiyeti ve siyasi fikirleri dolayısıyla hayatı ya da özgürlüğü tehdit altında olacak ülkelerin sınırlarına, her ne şekilde olursa olsun geri göndermeyecek ve iade ("refouler") etmeyecektir." ${ }^{67}$ Işkenceye ve Diğer Zalimane Gayriinsani veya Küçültücü Muamele veya Cezaya karşı Birleşmiş Milletler Sözleşmesi ve Suçluların İadesine Dair Avrupa Sözleşmesi de "geri gönderme yasağı" içermektedir. Avrupa İnsan Hakları Sözleşmesi'nde geri göndermeme (non refoulement) prensibinden açıkça söz edilmemiştir, bununla birlikte İnsan Hakları Sözleşmesi’nin 3. 8. ve 13. maddeleri

63 BMMYK, Sığınma ve Mülteci Konularındaki Uluslararası Belgeler ve Hukuki Metinler, (Ankara: Damla Matbaas1, 1998), 68.

64 BMMYK, Dünya Mültecilerinin Durumu, 52.

65 Odman, Mülteci Hukuku, 45-46.

66 Çiçekli, Yabancılar ve Mülteci Hukuku, 229,

Afrika Birliği Örgütünün mülteci tanımı: "Mülteci deyimi dış saldırı, işgal, yabancı egemenliği veya vatandaşı olduğu kendi ülkesinin bir bölümünde ya da bütününde kamu düzenini ciddi bir biçimde tehdit eden olaylar yüzünden, ülkesi dışında başka bir yere sığınmak için yaşadığı yerden ayrılmak zorunda kalan her insanı kapasar.” Böylesine kapsamlı bir mülteci tanımı, sömürgeciliğin tasfiyesi ve ulusal bağımsılık döneminde Afrikalı mülteciler sorunun büyümesinden dolayı Afrika Birliği Örgütü’nün 1969 tarihli Mülteci Sözleşmesiyle oluşturuldu. Orta ve Güney Amerika tarafından benimsenen Cartagena Deklarasyonu birlikte diğer bölgesel düzenlemelerde de, zülüm korkusunu daha az vurgulayan, ülkedeki şiddet ve karışıklığın nesnel koşullarını ön plana çıkaran tanımlar yapılmıştır ve bu tanımlamalar BMMYK tarafından da tercih edilmektedir. BMMYK, Dünya Mültecilerin Durumu, 52.

67 BMMYK, Sı̆̆ınma ve Mülteci Konularındaki Uluslararası Belgeler ve Hukuki Metinler, 77. 
sınırdan geri çevirme ve sınırdışı etme kararlarına engel olmak için kullanılmaktadır. Özellikle 3. madde (işkence yasağı) Avrupa İnsan Hakları Mahkemesi tarafindan geri göndermeme ilkesinin uygulanmasında sıklıkla başvurulan bir maddedir. ${ }^{68}$ Böylelikle sözleşmelere taraf ülkeler sı̆̆ınma başvurusunda bulunanların geldikleri ülkelere geri gönderilmeleri takdirde yaşamları açıkça tehdit altına girecekse geri dönmeye zorlamama yükümlülügüundedirler. ${ }^{69}$ Geri göndermeme ilkesi uluslararası geleneksel hukukun temel bir kuralı olduğundan dolayı Cenevre Sözleşmesi’ne taraf olmayan devletler de bu ilkeye uymak zorundadırlar. Gigauri'ye göre geri gönderme ilkesinin uygulanıyor olması dolaylı bir giriş hakkı sağlamaktadır, bu ilke devletin mutlak bir kabul etmeme yetkisi olmadığını göstermektedir. Devletlerin egemenliğini kısıtlayıcı, mültecilerin gönderilme riskini azaltıcı faktör olarak bu ilke, sığınmacılara bir hak vermemekte sadece devletlere bir zorunluluk yüklemektedir. ${ }^{70}$

Devletin söz konusu yükümlülükleri istisnalara bağlanmıştır. Sözleşmenin 32. maddesinde yer alan "Taraf Devletler, ülkelerinde yasal olarak bulunan bir mülteciyi, ulusal güvenlik veya kamu düzeni ile ilgili sebepler dışında sınır dişı edemeyeceklerdir." ${ }^{71}$ ifadesi istisnalardan biridir. Ulusal güvenlik kavramının uluslararası hukukta üzerinde uzlaşılan bir tanımı bulunamamaktadır. Kavramın içeriği daha çok egemen devletlerin politik, ekonomik, sosyal ve kültürel sistemlerine göre şekillenmektedir. ${ }^{72}$ Geri gönderme yasağına ilişkin istisnanın "kamu düzeni” ve "ulusal güvenlik" gibi muğlâk ifadelere dayandırılması, keyfi yorum ve uygulamalara neden olmaktadır. ${ }^{73}$

Günümüzde mültecilere yönelik keyfi uygulamaların arttığını belirten Birleşmiş Milletler Yüksek Komiserliği son zamanlarda ülkelerin sınırlarını açıkça kapattığını ya da bazılarının daha sinsice davranarak mültecilerin topraklarına girmesini engelleyen yasa ve yönetmelikleri yürürlüğe koyduğunu belirtir. ${ }^{74}$ Diğer taraftan egemen devletlerin mültecileri ve sığınmacıları sözde güvenli ülkelere gönderme yoluna başvurması da "iade etmeme" ilkesi üzerinde oynanmasını mümkün kılmaktadır. ${ }^{75} \mathrm{Ge}$ nel olarak geri göndermeme ilkesi yerine getirilmemektedir, öyleyse bugün Kant'in geri göndermeme ilkesinin bile epey uzağındayı.

Modern uluslararası hukukta sığınma hakkı ortaya çıkışından bu yana bir hak olarak değil devletlerin bahşettiği bir lütuf olarak algılanmıştır. Böylelikle sığınma hakkı devletlerin iç hukukuna veya diğer devletlerle yapacağı anlaşmalara bağlı bir egemenlik tasarrufudur. Diğer bir deyişle sığınma hakkı bireysel bir hak değildir, bu hakkın tanınması devletlerin tasarrufuna bırakılmış bir haktır yani bir devlet hakkidir. $^{76}$

68 Nuray Ekşi, Avrupa İnsan Hakları Mahkemesi Abdolkhani ve Karimnia - Türkiye Davası Mülteci ve Siğınmacı Hukuku Açısından Değerlendirme, (İstanbul: Beta, 2010), 26, 28.

69 Benhabib, Ötekilerin Haklarl, 45.

70 Savaşan, AB'de Sı̆̆ınma Hakkı, 18.

71 BMMYK, Siğınma ve Mülteci Konularındaki Uluslararası Belgeler ve Hukuki Metinler, 77.

72 Çiçekli, Yabancılar ve Mülteci Hukuku, 292.

73 Peker ve Sancar, Mülteciler ve İltica Hakkı, 31.

74 BMYYK, Dünya Mültecilerinin Durumu, 64.

75 Benhabib, Ötekilerin Hakları, 45.

76 Peker ve Sancar, Mülteciler ve İltica Hakkı, 8. 
Sığınma hakkına yansıyan bu anlayış birçok hak sözleşmelerinde yerini almıştır. Insan Hakları Evrensel Beyannamesi 14. maddesinde şu ifadeye yer verilmiştir: "Herkes zulüm karşısında başka ülkelerde sığınma talebinde bulunma ve sığınma olanağından yararlanma hakkına sahiptir". Bu madde de bahsedilen "talep etme ve yararlanma hakkı" dır. Yani sığınma talebinde bulunan kişinin herhangi bir hukuki korumaya sahip olması söz konusu değildir. Hukuki güvence başvurduğu devletin tasarrufuna bırakılmıştır. Devlet iç hukukuna ve taraf olduğu uluslararası anlaşmaları dikkate alarak bu hakkı tanıma veya tanımama yetki ve hakkına sahiptir. ${ }^{77} 1967$ tarihli BM Ülkesel Sığınma Bildirisinde sığınma hakkı temel ve kişisel bir hak olarak yer almamıştır. Dahası devletlerin sığınma hakkını tanıma konusunda sahip olduğu yükümlülüklere değinilmemiştir. ${ }^{78}$

Mültecilere bir takım yükümlülükler verilmiştir. Cenevre Sözleşmesi’nin 2. maddesinde "Her mültecinin, bulunduğu ülkeye karşı, özellikle yasalara, yönetmeliklere ve kamu düzeni için alınan önlemlere uymayı öngören yükümlülükleri vardır." ${ }^{79} \mathrm{Bu}$ yükümlülükler Derrida’nın "Evinizde gibi davranın ama konukluk kurallarına uymak koşuluyla, yani benim evimde oluşunuzun bana ait olduğunu göz önünde tutarak" ifadesini hatırlatmaktadır. Mültecilerin bulunduğu ülkenin yasalarına ve kültürüne ayak uydurma zorunluluğu belirtilmektedir. Böylece koşullu misafirperverliğin bir yansıması olarak mültecileri kabul eden ev sahibi efendi olarak kalmaktadır.

Cenevre Sözleşmesi’nin 31. maddesinde “Taraf Devletler, hayatlarının veya özgürlüklerinin, madde 1'de gösterilen şekilde tehdit altında bulunduğu bir ülkeden doğruca gelerek izinsizce kendi topraklarına giren veya bu topraklarda bulunan mültecilere, gecikmeden yetkili makamlara başvurarak yasadışı girişlerinin veya bulunuşlarının geçerli nedenlerini göstermeleri koşuluyla, yasadışı yollardan girişleri veya bulunuşlarından dolayı ceza vermeyeceklerdir" ${ }^{81} \mathrm{Bu}$ maddede kaçak giriş yapanların ceza almaması için geçerli neden gösterme koşulu Kant'ın "her vatandaşın geldiği ülkede düşmanca muamele görmeme hakkı"nı sağlayamamaktadır; ancak Derrida’nın koşullu misafirperverliğini içermektedir. ${ }^{82}$

Günümüz devletlerinin Kant'in en temel talebini dahi gerçekleştirmekten uzak olmasının nedenlerinden biri, uluslararası anlaşmaların yaptırımlarının egemen devletlerin yetkisine bırakılmasıdır. İnsan haklarının başlıca garantörünün ulus devlet olması yerinden edilmişlerin hakları konusundaki tartışmayı ulusal egemenlik iddiaları ile insan hakları talepleri arasına hapsetmektedir. Devletler ulusal çıkarlarını veya güvenliklerini dikkate alarak egemenliklerinin sınırlanmasına karşı çıkmakta ve insani yükümlülüklerini yerine getirmemektedirler. ${ }^{83}$

77 Savaşan, AB'de Sı̆̆ınma Hakkı, 16.

78 Peker ve Sancar, Mülteciler ve İltica Hakkı, 9.

79 BMMYK, Sı̆̆ınma ve Mülteci Konularındaki Uluslararası Belgeler ve Hukuki Metinler, 69.

80 Derrida, Konuksev (-er-/-mez-) lik, 28.

81 BMMYK, Sığınma ve Mülteci Konularındaki Uluslararası Belgeler ve Hukuki Metinler, 77.

82 S. Gizem Alpakgir Cevheri, "Mültecilik kavramının”.

83 Özgür Soysal “Evrenselcilik-Tikelcilik Gerilimi Işı̆̆ında Ötekiler’in Kaderi” (Birinci Uluslararası Felsefe Kongresi: Eşitlik, Özgürlük ve Kardeşlik Bildirileri, Uludağ Üniversitesi Fen Edebiyat Fakültesi, Bursa, 14-16 Ekim, 2010). 


\section{Türkiye’ye Yönelik Mülteci Hareketleri}

Türkiye Cumhuriyeti kuruluş yıllarından bu yana göç hareketlerine tanık olmuştur; ancak 1980’lere kadar ulus inşa etme politikası doğrultusunda “Türk kültür ve irkından gelen" göçmenlere ayrıcalık tanıyan bir sistem oluşturmuş ve neticede daha çok Türk kökenlilerin göç ettiği bir ülke statüsünde kalmıştır. Bu kapsamda 1934 İskân kanunu kabul edilmiştir. Bugün bile mültecilerin kabulünü İskân yasası kuralları belirlemekte ve Türk kültüründen olanlara öncelik tanımaktadır. ${ }^{84}$

1980 lerle birlikte Türkiye’ye yönelen göç hareketleri nitelik olarak değişmiştir. Bu tarihten sonra büyük çapta sığınma ve düzensiz göç yaşanmıştır. Böylece Türkiye’de yabancı uyruklu göçmen, sığınmacı oranı artmış ve Türkiye uluslararası göç bakımdan çoğunlukla geçiş bölgesi haline gelmiştir. ${ }^{85} 1980$ sonrası meydana gelen mülteci hareketleri Türkiye’yi büyük ölçüde etkilemiştir. Özellikle 1988-1991 İranIrak savaşı, 1990-1991 Körfez Savaşı ve son yıllarda Ortadoğu da yaşanan savaşlar Türkiye'yi etkileyen yoğun nüfus hareketleridir. ${ }^{86}$

Böylelikle Türkiye’ye göçmen değil ama daha çok yabancı olarak adlandırılan kişilerin kitlesel akınları meydana gelmiştir. Bu durum Türkiye’nin uluslararası göç rejimindeki konumunu değiştirmiştir. Bunun sonucunda önceleri sadece göç veren ülke iken artık göç alan ve geçiş ülkesi durumuna da geçerek üçlü bir konuma geçmiştir. $^{87}$

Avrupa'ya yönelen göç için geçiş bölgesi haline gelen Türkiye'nin göç politikası Avrupa Birliğìne tam üyelik sürecinde değişime uğramıştır. Bu süreçte Türkiye’nin yasal göç, düzensiz göç ve iltica konularında kapsamlı değişiklik yapılması öngörülmüştür. 2000 tarihinde imzalanan AB ile ilk Katılım Ortaklığı Belgesi ile bu alanda bir uyum süreci yaşanmış ve Türkiye göç politikasında AB’ye bağımlı bir hale gelmiştir. 19 Mayıs 2003 tarihli “yeni katılım ortaklığı belgesi”, 24 Temmuz 2003 tarihli "ulusal program”, 25 Mart 2005 tarihli “iltica ve göç ulusal eylem planı” belgeleri Türkiye’nin yasadışı göçün önlenmesine yönelik kabul, geri kabul ve sınır dışı etme uygulamalarında $\mathrm{AB}$ müktesebatının kabul edilmesi ve uygulanmasına yer vermiştir. ${ }^{88}$

\section{Mülteci Hukuku ve Türkiye}

1951 tarihli “Mültecilerin Hukuki Durumuna Dair Cenevre Sözleşmesi” ve 1967 tarihli "Mültecilerin Hukuki Statüsüne İlişkin Protokol” uzun bir süre Türkiye hukukunda mültecilerle ilgili başlıca yasal düzenleme olmuştur. Çünkü Türkiye’de mültecilerin hukuki durumunu kanun düzeyinde ele alan bir yasal düzenleme

84 Ahmet İçduygu, Sema Erder ve Ömer Faruk Gençkaya, Türkiye’nin Uluslararası Göç Politikaları 1923-20023: Ulus Devlet Oluşumundan Ulus Ötesi Dönüşümlere (İstanbul, MireKoç, Ocak 2014), 239.

85 Cansu Güleç, “Avrupa Birliği'nin Göç Politikaları ve Türkiye’ye Yansımaları”, Tesam Akademi Dergisi 2/81-100 (2015): 92-93.

86 Nasıh Sarp Ergüven ve Beyza Özturanlı, "Uluslararası Mülteci Hukuku ve Türkiye”, Ankara Üniversitesi Hukuk Fakültesi Dergisi, 62: 4 (2013), 1025 (erişim 10.09.2016).

87 Serdar Ünal, Türkiye’nin Beklenmedik Konukları: "Öteki Bağlamında Yabancı Göçmen ve Mülteci Deneyimi”, Zeitschrift für die Welt der/Türken journal of World of Turks 6/3 (2014): 68.

88 Güleç, “Avrupa Birliği'nin Göç Politikalar”, 93. 
bulunmamaktaydı. 1951 Cenevre Sözleşmesi ve 1967 Protokolü temel alınarak hazırlanan 1994 "iltica ve sığınma yönetmeliği” uygulamalara yön vermekteydi. Bu mevzuat dışında mülteci ve sığınmacı ilgili işlemler büyük oranda İçişleri Bakanlığ tarafından çıkarılan genelgeler ve talimatlar tarafından uygulanmaktaydı. ${ }^{89}$

Türkiye 1951 Cenevre Sözleşmesi’ne ve bu sözleşmeye ek 1967 Protokolü’ne coğrafi kısıtlama şartıyla taraf olmuştur. Bu kısıtlama gereği Avrupa dişından gelen sı̆̆ınmacılara mülteci statüsü tanımayacağını bildirmiştir. ${ }^{90}$ Türkiye’nin coğrafi sınırlama anlayışı sığınma rejimini zora sokmaktadır. Türkiye bu uygulama ile Asya ve Afrika'daki fakir ve istikrarsız ülkelerden gelen göç akımına karşı önlem almak istemektedir. Türkiye coğrafi kısıtlama olmazsa siyasi karmaşaların yaşandığ ${ }_{1}$ ülkeler ile Avrupa arasında tampon bölge haline gelmekten endişe etmektedir. Bundan dolayı Türkiye'deki yetkili kurumlar kısıtlamanın kalkmasına karşı çıkmaktalar ve sadece $A B$ üyeliği durumunda gündeme alınabileceği dile getirmekteler. ${ }^{91}$ Türkiye’nin coğrafi sınırlaması mültecilere ilişkin yasal düzenlemeleri "geçicilik" esası üzerine inşa etmesine yol açmıştır.

Bu bakımdan 1994 Yönetmeliği Avrupa dışından gelen mülteciler için "geçicilik" esasına dayanmaktadır. İlk ulusal mevzuat olma açısından önemli olan 1994 Yönetmeliği'nde yasal prosedürün hangi aktörler tarafından uygulanacağını ve geçici korumanın nasıl uygulanacağı konusu ilk kez belirtilmiştir. 1994 Yönetmeliği öncesinde BMMYK Avrupa dışından gelenlerin statülerini belirleyen ve yerleştirme işlemlerini yürüten kurum olarak faaliyet göstermiştir. 1994 Yönetmeliği sonrasında BMMYK’nin yürütme sorumluluğu değişmezken, statü belirlemede verdiği kararı devlet otoriterlerine danışması gerekliliği getirilmiştir. Bu durum birbirine paralel ama farklı kurumların yönettiği iki iltica prosedürüne aynı zamanda aynı başvuru için bazı durumlarda farklı kararların alınmasına yol açmıştır. Yani aynı bireye, iki farklı hukuk sistemi üzerinden işleyen bir uygulama hayata geçirilmiştir ve sonucunda çok parçalı bir yapı kurumsallaşmıştır. ${ }^{92}$

1994 yönetmeliği iltica konusunda birçok eksikliğe sahiptir. Bu durum Avrupa İnsan Hakları Mahkemesi'nin Türkiye aleyhine verdiği kararlarda görülmektedir. Bundan dolayı sonradan çıkarılan yönetmelik ve yasalarla bu eksiklik kapatılmaya çalışılmıştır. 1994 Yönetmeliği, Türkiye’de sığınma işlemleri devam eden ve hatta BMMYK aracılığıyla üçüncü devletlerde sığınma hakkı elde eden sığınmacıların on gün içerisinde valiliklere başvuramadıkları takdirde sınır dışı edilebilmelerine neden olmuştur. Avrupa İnsan Hakları Mahkemesinin Jabari ${ }^{93}$ davasında verdiği ihlal ka-

89 Çiçekli, Yabancılar ve Mülteci Hukuku, 238-239.

90 BMMYK, İltica, Uluslararası Göç ve Vatansızlık: Kuram, Gözlem ve Politika (Ankara: Anıl Reklam Matbaacılık, 2011), 51.

91 İçduygu, Erder ve Gençkaya, Türkiye’nin Uluslararası Göç Politikaları, 237.

92 Özge Biner, Türkiye’de Mültecilik, İltica, Geçicilik ve Yasallık "Van Uydu Şehir Örneği” ( İstanbul: İstanbul Bilgi Üniversitesi Yayınları, 2016), 92-93.

93 Hoda Jabari İran yasalarına göre zina suçu işlediğinden ceza davası başlamadan önce İran’ı terk etmiştir. 1997 Kasım’nnda Jabari yasa dışı yollardan Türkiye’ye girmiştir. Şubat 1998’de sahte pasaportla İstanbul üzerinde Fransa’ya gitmiş ve Paris havaalanında Fransız polisi tarafından sahte pasaport kullandığı gerekçesiyle İstanbul’a geri gönderilmiştir. İstanbul havaalanında inmesinin ardından sahte pasaport kullanma ve yasa dışı yollardan Türkiye’ye giriş yapma gerekçesiyle gözaltına alınmıştır. İstanbul Emniyet Müdürlüğü Hudut İltica ve Yabancılar 
rarı bu konuda değişikliğe gidilmesinin zorunluluğunu hatırlatmıştır. Böylece önceden beş günlük olan başvuru süresi on günlüğe çıkartılmıştır. Daha sonra 2006 tarihli yönetmelikle on günlük başvuru süresi yerine "gecikmeden" ve "makul olan en kısa süre içerisinde” ifadeleri getirilmiştir. Fakat sığınma hakkı kabul edilmeyenlerin on beş gün içerisinde ilgili valiliklere itiraz hakkını düzenleyen hükme istisna getirilmiştir. İçişleri Bakanlığı gerekli gördüğü durumda bu süreyi daha kısa olarak belirleyebilecektir. Bakanlığa itiraz hakkını tamamen ortadan kaldırabilecek bir yetki verilmiştir. $^{94}$

6458 Sayılı Yabancılar ve Uluslararası Koruma Kanunu (YUKK) ile birlikte ilk defa mültecilerin hukuki durumuna yönelik konular kanun düzeyinde bir yasal temele kavuşmuştur. 1994 yönetmeliği toplu sığınma konusunu düzenlemekteydi. Geçici koruma olarak adlandırılan bu olgu 2011 yılından beri Suriye'de devam eden iç savaş nedeniyle Türkiye’ye gelen Suriye uyruklu yabancılar için de sağlanmıştır. "Türkiye’ye Toplu Sığınma Amaciyla Gelen Suriye Arap Cumhuriyetinde İkamet Eden Vatansız Kişilerin Kabulüne ve Barındırılmasına İlişkin Yönerge” adlı Bakanlık düzenlemesi Suriyeli mülteciler için geçici koruma düzenlemesini içermektedir. ${ }^{95}$

YUKK'da geçicilik esası üzerinde kurgulanmış ve hazırlanmıştır. Devlet, iltica sistemini hâlâ çok sayıda devlet ve devlet dışı aktörün aynı anda farklı derecelerde dâhil olduğu mekanizma üzerinde yürütmektedir. ${ }^{96}$ BMMYK ile devlet statü belirlemek için gerçekleştirdikleri mülakat sonucunda aynı fikirde olsalar da verdikleri statü ve haklar farklıdır. Devlet sığınma talebini haklı bulduğu durumda "şartlı mülteci" statüsü verirken BMMYK ise "mülteci” statüsü vermektedir. Böylece devlet bireye üçüncü bir ülkeye yerleştirilene kadar ülkede geçici olarak kalma hakkı olarak "şartlı mülteci” statüsü tanımıştır. ${ }^{97}$

YUKK'da coğrafi sınırlama kapsamında üç farklı şekilde uluslararası koruma statüsü tanımlanmıştır: "mülteci”, "şartlı mülteci” ve "ikincil koruma”. Mülteci statüsü Avrupa ülkelerinden gelen mültecilere verilmektedir. Şartlı mülteci statüsü ise Avrupa ülkeleri dışından gelen mültecilere verilmektedir. 1951 Cenevre Sözleşmesi’ne uygulanan coğrafi kısıtlama nedeniyle 1994 Yönetmeliği’ndeki mülteci ve sığınmacı ayrımı yine aynı düşünceyle mülteci-şartlı mülteci ikilemi içerisinde kullanılmıştır. ${ }^{98}$

Şubesi, Jabari’nin Irak’a sınırdışı edilmesine karar vermiştir. Jabari, İran vatandaşı olduğunu belirterek mülteci talebinde bulunmuştur. Ancak mülteci başvurusunu 1994 Yönetmeliğinde öngörülen beş günlük süre içinde yapmadığından dolayı reddedilmiştir. Daha sonra BMMYK devreye girmiş ve Jabari’nin İran’a gönderildiği takdirde gerçek anlamda ölüm ve işkence tehlikesiyle karşılaşacağından dolayı mülteci statüsü vermiştir. 8 Mart 1998'de Jabari sınırdışı edilme kararına karşı Ankara İdare Mahkemesi’ne başvurmuş ve yürütmenin durdurulmasını istemiştir. Mahkeme Jabari’nin talebini reddetmiştir. Bu durumda Jabari İHAM'a başvurmuştur. İHAM başvurusu sonuçlanan kadar Türkiye’de kalmasına izin verilmiştir. İHAM Türkiye’nin 13. maddeyi (etkili başvuru hakkı) ihlal ettiğine ancak snırdışı kararının uygulanmadığından dolayı 3. maddenin (işkence yasağı) ihlalinden söz edilemeyeceğine karar vermiştir.

Nuray Ekşi, Avrupa İnsan Hakları Mahkemesi Abdolkhani ve Karimnia Türkiye Davası Mülteci ve Siğınmacı Hukuku Açısından Değerlendirme (İstanbul: Beta, 2010), 35-36.

94 Ergüven ve Özturanlı, "Uluslararası Mülteci Hukuku”, 1027-1028.

95 Çiçekli, Yabancılar ve Mülteci Hukuku, 239.

96 Biner, Türkiye'de Mültecilik, 93.

97 Biner, Türkiyede Mültecilik, 97.

98 Çiçekli, Yabancılar ve Mülteci Hukuku, 251- 252. 
Yani 1994 Yönetmeliği’nde yer alan sığınmacı statüsünün yerini şartlı mülteci statüsü almıştır.

YUKK, geri göndermeme ilkesini kabul etmekte ve 1994 Yönetmeliği’nde yer almayan bir uluslararası koruma statüsü olarak "ikincil korumayı" getirmektedir. İkincil koruma mülteci ve şartlı mülteci olarak nitelendirilmeyenlere verilen statüdür. ${ }^{99}$

Geçici koruma ise kitlesel sığınma akınlarında bireysel statü belirleme usullerine başvurmaksızın grup temelinde mülteci statüsü verilerek acil koruma ihtiyaçlarını gidermeyi sağlamaktadır. Geçici korumanın amacı mülteci ve sığınmacıların acilen güvenli bir ortama ulaşmalarını sağlamak ve temel insan haklarını koruma altına almaktır. $^{100}$

Geri göndermeme ilkesinin bir sonucu olan geçici koruma statüsü Avrupa Birliği’nde ilk olarak 1990'lı yılların başlarında Yugoslavya krizinden dolayı ortaya çıkan kitlesel sığınma olayları ile gündeme gelmiştir. ${ }^{101}$ Günümüzde ise bu statü Suriye’de yaşanan iç savaş nedeniyle ortaya çıkan kitlesel sığınma olayları ile gündeme gelmiştir. Başlangıçta "misafir" olarak adlandırılan Suriyeli mültecilere "geçici koruma" statüsü verilmiştir.

Türkiye'nin iltica düzenlemelerinin bir başka niteliği ise sığınmacılara-mültecilere sağlanan hakların ve imkânların kısıtlı tutulması ve yasal olarak tanınmış hakların sağlanmasına ilişkin işlemlerin kolaylaştırılmasını sağlayan etkin kurumsal bir yapının olmayışıdır. Bu hususlar göstermektedir ki Türkiye’nin iltica düzenlemeleri "mülteci yükü almamak" amacına yöneliktir. Türkiye’nin mülteci yükü almama amacı işlevsel olamamaktadır. Ülkeye önemli sayıda sığınmacı girebilmektedir. Mülteci statüsü olmasa da sığınmacı adı altında uzun bir süre kalabilmektedirler. ${ }^{102}$ Fakat mülteci statüsü altında değerlendirilmemeleri temel insanı haklardan mahrum olmalarına, güvencesiz ve belirsiz bir yaşam sürmelerine neden olmaktadır.

Türkiye'nin Cenevre Sözleşmesi’ne coğrafi çekince şartıyla taraf olmasından dolayı Avrupa dışından gelenlerin mültecilik haklarından yararlanamaması böylelikle mültecinin belirsizliğe bırakılması, kişinin Türkiye’ye giriş yapıp yapamayacağına karar verecek olanın çoğunlukla jandarma eri veya polisin olması, ${ }^{103}$ mültecilerin gözetim altında alınmasıyla ilgili standartların belirlenmemiş olması, gözetim altına alma işlemine yönelik itiraz yollarının ilişkin açık bir düzenlemenin olmayışı, mülteci misafirhanelerinin koşullarının uygunsuzluğ ${ }^{104}$ gibi birçok sorun Derrida’nın ifade ettiği gibi "misafirperverlik ihlalleri”ne yol açmaktadır.

\section{İstenmeyen "Misafir": Suriyeli Mülteciler}

Birleşmiş Milletler Mülteci Yüksek Komiserliği’nin 2016 yılı verilerine göre 2011 yı-

99 Ergüven ve Özturanlı, "Uluslararası Mülteci Hukuku”, 1037.

100 Çiçekli, Yabancılar ve Mülteci Hukuku, 313-314.

101 Çiçekli, Yabancılar ve Mülteci Hukuku, 216.

102 BMMYK, İltica, Uluslararası Göç ve Vatansızlık, 52-53.

103 Peker ve Sancar, Mülteciler ve İltica Hakkı, 46.

104 Ergüven ve Özturanlı, “Uluslararası Mülteci Hukuku”, 1054. 
lından bu yana yaklaşık 4 milyon Suriyeli ülkesinden kaçtt. ${ }^{105}$ Ülkesini terk edenlerin yaklaşı olarak 2.7 milyonu Türkiye’ye, 1 milyonu Lübnan’a, 655 bini Ürdün’e, 225 bini Irak’a, 117 bini Mısır’a gitmiştir. ${ }^{106}$ Türkiye'de bulunan Suriyeli mülteciler başta İstanbul, Gaziantep, Şanlıurfa, Hatay illerinde yoğunlukta bulunmaktadır. ${ }^{107} \mathrm{Bu}$ veriler sadece kayıtlı olanları vermektedir.

Türkiye mülteci ve sığınmacılara aşina olmasına rağmen Türkiye için Suriyeli mülteciler beklenmedik bir durum yaratmıştır. Bunun nedeni hızla artan mülteci sayısının Türkiye tarihindeki diğer mülteci akınlarına benzememesi ve geçmişteki uygulamalarından önemli bir sapmaya işaret olarak Avrupa dışından gelmiş bu kadar fazla sayıda mülteciye yönelik "açık kapı politikası" uygulamasıdır. ${ }^{108} \mathrm{Bu}$ durum karşısında; mülteci akının başlarında Türkiye' deki yetkililer Suriyeli mültecileri hiçbir yasal karşıllğı olmayan "misafir" kavramıyla tanımlamayı tercih etmiştir. Misafir statüsünün hukuki karşıllğ̆ olmamasından dolayı "geçici koruma" adı altında yeni bir statü oluşturulmuştur.

YUKK'un 91. Maddesi çerçevesinde "geçici koruma yönetmeliği” hazırlanarak Suriyeli mültecilere "geçici koruma" statüsü verilmiştir. Türkiye, geçici koruma rejimi ile geri göndermeme ilkesini ve Suriyelilere sağlık ve barınma gibi hizmetleri sağlayacağını kendiliğinden kabul etmiş olmaktadır. ${ }^{109}$ Geçici Koruma Yönetmeliği’nde sağlık, eğitim, barınma ve çalışma hakkı düzenlenmiştir. Uluslararası Af Örgütünün 2014 tarihli raporuna göre, eğitim hakkı bürokratik şart, dil sorunu ve maddi kısıtlama engeline takılmaktadır. Aynı zamanda bazı okulların mülteci çocukları kaydetmek konusunda isteksizliği de etkili olmaktadır. ${ }^{110}$ Kamu hastanelerinden ücretsiz yararlanabilme hakkı düzenlenmiş; ancak kronik hastalar bu kapsam dışında bırakılmıştır. Dil sorunu, ilaçların maliyeti, Suriyeli mültecilerin sağlık kurumlarına nasıl ulaşacakları konusunda bilgilendirilmemeleri gibi bir dizi erişim engeli bulunmaktadır. ${ }^{111}$ Yönetmelikte ikamet izni alma şartı olmaksızın Bakanlar Kurulu tarafından belirlenecek sektör ve yerlerde çalışma izni alabilmek için doğrudan başvuru hakkı bulunmaktadır. Fiiliyatta ise denetimler yapılmamakta ve işverenlerin mültecileri ucuz iş gücü olarak sömürmesine göz yumulmaktadır. ${ }^{112}$

Kısaca geçici koruma, geri gönderilmemeye karşı koruma ve acil ihtiyaçları karşılamayı içeren bir düzenlemeden oluşmaktadır. Kamp dışında yaşayan ve büyük çoğunluğu oluşturan Suriyeli mülteciler kayıtlı olmadığı müddetçe söz konusu hak-

105 "Syria Emergency", son güncelleme 29 Ekim, 2016, http://www.unhcr.org/syria-emergency.html.

106 "Syria Regional Refugee Response", son güncelleme 29 Ekim, 2016, http://data.unhcr.org/syrianrefugees/ regional.php.

107 Murat Erdoğan, Rapor: Türkiye’deki Suriyeliler: Toplumsal Kabul ve Uyum Araştırması, (Hacettepe Üniversitesi Göç ve Siyaset Araştırmaları Merkezi, Kasım 2014), 14.

108 Kemal Kiriş̧̧i, Rapor: Misafirliğin Ötesine Geçerken "Türkiye’nin Suriyeli Mülteciler Sinavı, çev., Sema Karaca, (Brooking Enstitüsü ve USAK, Haziran 2014), 14.

109 Kirişçi, Rapor: Misafirliğin Ötesine Geçerken, 21.

110 Uluslararası Af Örgütü, Rapor: Hayatta Kalma Mücadelesi: Türkiye’deki Suriye’den Gelen Mülteciler, Kasım 2014,31 .

111 Uluslararası Af Örgütü, Rapor: Hayatta Kalma Mücadelesi, 33-34.

112 Uluslararası Af Örgütü, Rapor: Hayatta Kalma Mücadelesi, 25. 
lardan yararlanamamaktadır. Kayıtlı olanların ise haklara erişiminde birçok engel bulunmaktadir.

Geçici koruma yönetmeliğini AB'den esinlenen Türkiye kavramın içini AB hukukun açılımından oldukça farklı düzenlemiştir. AB hukukunda geçici koruma adının çağrıştırdığ 1 gibi geçici bir çözüm olarak tarif edilmiştir. En fazla üç senelik bir koruma sağlanmakta ve ülkelerini terk edenlerin terk etme sebeplerinde iyileşme olmadığı gözlenirse uzun vadeli bir yol düşünülmektedir. Oysa Türkiye'de geçici koruma da süre sınırlaması yok ve bu korumanın ilanı da sona erdirilmesi de Bakanlar Kurulunun takdirine yani hükümete bağlıdır. ${ }^{113}$

Görüldüğü üzere bir süre kısıtlaması bulunmayan Geçici Koruma Yönetmeliğìnde genel olarak "şartlı mültecilere" imkanlar ölçüsünde sağlanabilecek hizmetlerin çerçevesi çizilmiştir. Dolayısıyla mülteci haklarından ve devletin yükümlülüğünden bahsedilememektedir. Daha çok misafirlere ev sahibinin gösterdiği iyi niyet mantığı düzenlemeye egemen olmuştur. ${ }^{114} \mathrm{O}$ halde Suriyeli mülteciler için benimsenen geçici koruma politikasının uzun vadeli bir stratejinin olmayışı, geçicilik üzerinden kurulması istisna halini kurallaştırmaktadır. Agamben, istisna olan her ne kadar genel kuralın dışına itilse de kuralla ilişkisinin devam ettiğini ifade eder. Yani istisna olarak dışlanan, kuralla ilişkisini kuralın askıya alınması şeklinde devam ettirmektedir. Bu bakımdan istisnai durum bir kaos değil; düzenin askıya alınmasından doğan bir durumdur. $\mathrm{Bu}$ da göstermektedir ki tamamen dişarıya terkedilen değil, dışarıda tutulan şeydir. ${ }^{115}$ Hayat ile hukukun, dışarıdaki ile içeridekinin birbirinden ayırt edilemediği, eşik alana bırakılan ${ }^{116}$ Suriyeli mültecilere yönelik ağarlamanın Derrida’nın düşüncesinden hareketle eşikle sınırlı olduğu söylenebilir. Çünkü Derrida misafirperverlik yasasında bir sınırlama, kendiyle çelişmenin olduğunu belirtir. Yasa olarak sunulan misafirperverlikte evin sahibinin kendi efendiliğini onaylatması olarak sunulan misafirperverlik kendini eşikle sınırlar. ${ }^{117}$ Yani Derrida kuralların, yasaların olduğu yerde misafirperverlikten bahsedilemeyeceğini, misafirperverliğin etik olması gerektiğini söyler. Kuralların olduğu yerde misafirperverlik eşiktir, koşulludur; yani misafirperverlik yoktur.

Misafirperverliğin öne sürdüğünün karşıtını yapması, çelişik yapısı Hacettepe Üniversitesi Göç ve Siyaset Araştırmalara Merkezi’nin (HUGO) Suriyeli mültecilere yönelik hazırladığı rapor kapsamında yerel hakla yapılan görüşmelere yansımıştır. Türkiye'de daha ne kadar kalabileceklerini bilmediklerini, kendilerini savunmasız hissettiklerini ve Suriye'ye gönderilmekten korktukları için polise şikayette bulunmaktan ve kayıt olmak için bile yetkililere gitmekten çekindiklerini ifade eden Suriyeli mülteciler ${ }^{118}$, HUGO' nun 2014'te yaptığı kamuoyu araştırmasına katılanların yüzde 72 si tarafından "zülumden kaçan insanlar", "misafirlerimiz" ve "din kardeş-

113 Helsinki Yurttaşlar Derneği, Saha: Göçmenlerin Aynasında Türkiye (İstanbul: Mart Matbaa, 2016), 21. 114 Murat Erdoğan, Rapor: Türkiye'deki Suriyeliler, 17.

115 Giorgio Agamben, Kutsal İnsan: Egemen İktidar ve Çıplak Hayat, çev., İsmail Türkmen (İstanbul, Ayrıntı Yayınları, 2013), 28.

116 Agamben, Kutsal İnsan, 40.

117 Derrida, "Konuksev (-er-/-mez-) lik, 28.

118 Uluslararası Af Örgütü, Rapor: Hayatta Kalma Mücadelesi, 21. 
lerimiz" olarak tanımlanmaktadır. ${ }^{19}$ Aynı zamanda yerel halk Suriyelilerin gelmesi ile huzurlarının bozulduğunu, eskiden kapı pencere açık uyurken artık her yeri hırsızların, kabadayıların sardığına dair pek çok şikayette bulunmuştur. Suriyelilerin misafir olduğu bundan dolayı uyum göstermek zorunda oldukları vurgulanmıştır. ${ }^{120}$ Bu bağlamda misafirperverlik Derrida’nın ifadesiyle düşmanlığı, kendi çelişkisini de içinde barındırmaktadır.

Misafirperverliğin içerdiği düşmanlık imgesi yeni gelenlerin farklılığıyla değişimin elle tutulur timsali olmalarından kaynaklıdır. Değişimden, eski güvenliğin yitiminden, eski adetlerin gözden düşmesinden, şimdiki durumun belirsizliğinden ve geleceğin getirebileceği felaketlerden bizzat yeni gelenler sorumlu tutulur. ${ }^{121} \mathrm{Bu}$ yaklaşım HUGO' nun yaptığı çalışmaya da yansımıştır. Söz konusu çalışmada kültürel farklıllğa vurgu yapan, Suriyelilerin varlığını sorun olarak görenlerin sayısının son derece yüksek olduğu belirtilmiştir. Suriyeli mültecilerin bulundukları yerde şiddet, hırsızlık, kaçakçlık ve fuhuş gibi suçlara bulaşarak toplumsal ahlak ve huzuru bozduklarına dair önermeye yüzde 62,3 lük oranla büyük destek verildiği belirtilmiştir. Özellikle bölge illerinde bu oranın neredeyse iki katına çıktığı vurgulanmıştır. Mültecilerin bu şekilde tehdit olarak algılanmasının temelini Agamben, modern ulus devlet yapısının kriziyle ortaya koymaktadır. Agamben mültecilerin modern ulus-devlet düzeni içinde bu kadar rahatsızlık verici unsur oluşturma nedenini mültecilerin insan ile vatandaş, doğum ile milliyet arasındaki sürekliliği kopartarak, modern egemenliğin orijinal kurgusunu krize sokmasına bağlamaktadır. ${ }^{122}$

Derrida, misafirperverlik kavramının düşman, istilacı gibi anlamları içinde barındırdığını; bundan dolayı sorunlu, çelişkili olduğunu belirtmiştir. Misafirperverliğin öznesi, evin efendisi olarak oraya kimi davet edeceğine karar veren bir ev sahibidir. Ancak böylesine egemen oto-kontrolden dolayı ev sahibi, evini istila ederek onu bir ev sahibinden (host) esire dönüştürmekle (hostage) tehdit eden bazı ötekilerden korkmaya başlar. Bundan dolayı misafirperverlik kanunları her ev sahibine kimi evine alacağına ve kimi dışarıda bırakacağına dair ayrımcılık hakkı tanır. Böylesi bir ayrımcılık ziyaretçinin kimliği saptamaya dayanır ve bu süreç belli düzeyde şiddet içerir. ${ }^{123}$ İşte bu işgal edilme hissi ile oluşan şiddete 2014 yllında Ankara, Gaziantep, Kahramanmaraş ve Adana'da yapılan "Suriyeliler gitsin" gösterileri ${ }^{124}$ örnek verilebilir.

Mülteciye, yabancıya ve ötekiye karşı bu tarz önyargı durumuna ilişkin kapsamlı analiz Nobert Elias'ın yerleşikler ve dişarlıklılar teorisinde ortaya konmaktadır. Elias’a göre dışarlıklıların içeriye akın etmesi her zaman yerleşik olanın hayat biçimine bir kafa tutuş demektir. Yeni gelenlere yer açma zorunluluğu ve dışarlıklıların kendilerine yer bulma ihtiyacından dolayı doğan gerilim her iki tarafın farklılıkları abartma-

119 Murat Erdoğan, Rapor: Türkiye’deki Suriyeliler, 30.

120 Murat Erdoğan, Rapor: Türkiye'deki Suriyeliler, 22-23.

121 Zygmunt Bauman, Sosyolojik Düşünmek, çev., Abdullah Yılmaz ( İstanbul, Ayrıntı Yayınları, 2015), 60.

122 Agamben, Kutsal İnsan, 158.

123 Richard Kearney, Yabancilar, Tanrilar ve Canavarlar, 91.

124 Murat Erdoğan, Rapor: Türkiye'deki Suriyeliler, 34. 
sına neden olur. Ancak yerleşiklerin önyargılarını harekete geçirme için daha iyi kaynakları bulunmaktadır. Yerleşikler daha uzun bir yerleşime sahip oldukları için "burası bizim atalarımızın toprağıdır" argümanına dayanarak hak iddia etmektedirler. Dışarlıklılar ise yalnızca farklı ve yabancı değildirler; aynı zamanda istilacı ve işgalci olarak görülürler. ${ }^{125} \mathrm{Bu}$ bakımdan Gaziantepliler, Suriyelilerle ilgili şikayetlerinde Suriyelilerin parklarda, hastane kuyruklarında, otobüslerde çok fazla görünür olduğunu; bu nedenle ailece oturamadıklarını ve yer bulamadıklarını dile getirmişlerdir. Mazlumder'in Gaziantep'te Suriyelilere yönelik saldırı ve nefretin sebeplerinin analizine dair raporuna yansıyan bu şikayetler Suriyelilerin kamusal alanlarda görünür olmaları ile yerel halkın kendi kültürüne bir tehdit olarak algılanmasıyla ilişkilidir. Suriyelilerin gelmesiyle eskiden "yerli” olan kent kültürüne zamanla melezliğin hâkim olduğu düşüncesi kendi kültürünün yok olacağı endişesini diriltmekte ve yabancıyı istilacı olarak görme eğilimini güçlendirmektedir. ${ }^{126}$ Kamusal alanda konuşulan ve dükkânlara tabela olan bir dilin yaygınlaşıyor olmasının Gazianteplilerin "artık nerede yaşadığına şaşırması” ve bunu şikâyet unsuru olarak belirtmesi böylece "kendini güvende hissetmemek", "kendini evinde hissetmemek" durumunun yaşanması evin işgal edildiği düşüncesinden kaynaklanmaktadır. ${ }^{127}$ Böylelikle evin efendisi olarak yerel halk Suriyeli mültecilerin evlerine (ülke, şehir vs.) girmeleriyle öznelerinin kesintiye uğramasından korkmaktadır. Bu durumda koşullu bir misafirperverliğin doğal yansıması olarak evin mülkiyetinin ve evin efendisinin konumunun muhafaza edildiğini görmekteyiz. Bu anlamda bir misafirperverliğe itiraz eden Derrida, ötekinin koşullu karşılanmasında iktidar konumunun sürdürülme tehlikesine karşı uyarıda bulunmaktadır. ${ }^{128}$

Türkiye basınında Suriyeli mülteciler üzerine yapılan haberlerde de işgal hissi yaratılmaktadır. Suriyeli mültecilerin sayısal çokluğunu anlatmak için tercih edilen "dalga", "akın”, "sel”, “yangın” ve "patlama” metaforları tarafından ülkenin mülteciler tarafından işgal edildiği ve "biz"in güvenliğinin tehlikede olduğu algısı yaratılmaktadır. Suriyeli mültecilerin 2011 yılında başlayan ilk gelişleri “Türkiye göç dalgasına hazırlanıyor” (Zaman 29.04.2011), “Türkiye’ye sığınmacı akını yaşanabilir”(Posta 25.12.2012), "Suriyeliler Türkiye’ye akın ediyor" (Zaman 06.11.2011) haber başlıklarıyla verilmiştir. Görüldüğü gibi önlenemez bir felaketle ilişkili olan dalga akın kavramları ile yıkıcılık, işgal durumu çağrıştırılmıştır. ${ }^{129}$ Sonraki yıllarda yapılan haber başlıklarında da aynı imgelerle karşılaşılmaktadır. “TEM'de Suriyeli mülteci seli! (Posta 15.09.2015), "Suruç'un nüfusu patladı" (Hürriyet 23.09.2014) şeklinde haber başlıkları yer almıştır. Mültecilerin nüfusunun artışının yaratacağı tehlike algısı "patlama" metaforuyla, mültecilerin istila ettiği algısı "akın" ve "sel" metaforuyla yansıtılmıştır. ${ }^{130}$ Söz konusu metaforlar misafirperverliğin içinde barındırdığg "biz” ve

125 Bauman, Sosyolojik Düşünmek, 60.

126 Abdurrahim Çelik vd., Gaziantep’te Suriyelilere Yönelik Saldırılar ve Toplumsal Nefretin Sebeplerinin Analizine Dair Rapor (Mazlumder, Kasım 2014), 27.

127 Çelik vd. Gaziantep’te Suriyelilere Yönelik, 29.

128 Yeğenoğlu, Avrupa'da İslam, 14.

129 Hatice Çoban Keneş, "Metaforun Ayrımcı Hegemonyanın İnşasındaki Rolü:Suriyelilerin Haberleştirilmesinde Metafor Kullanımı”, Gaziantep Sosyal Bilimler Dergisi 15/2 (2016): 261.

130 Keneş, "Metaforun Ayrımcı", 263. 
"onlar” ayrımını, ev sahibinin iktidarını, yabancının/ötekinin evi işgal ettiği algısını göstermektedir.

Misafirin eve yönelik bir tehdit olarak algılanması linç girişimlerine yol açabilmektedir. Bu durumda oluşan gerginlikler medyada "Suriye gerginliğì", "Aman Dikkat" gibi haber başlıklarıyla verilerek gerginliğin kaynağı olarak linçe maruz kalanlar gösterilmektedir. ${ }^{131}$ Hrant Dink Vakfinın 2014 tarihli medyada nefret söylemi ve ayrımcı dil raporunda hem ana akım medyada hem Antep yerel basınında Suriyeliler bizim misafirlerimiz kardeşimiz olarak yansıtıldığı istenmeyen durumlar yaşandığında ise Suriyelilere "sağduyu", "sabır" ve "hoşgörü" ile yaklaşılması söylendiği belirtilmektedir. ${ }^{132}$ Örneğin Olay gazetesinin 14 Ağustos 2014 tarihinde birinci ve ikinci sayfadan verdiği haberde Gaziantep Büyükşsehir Belediye Başkanı Fatma Şahin'in sağduyu çağrısı verilmiştir, mülteci yerine "misafir" kelimesi vurgulu biçimde yer almıştır. ("Şahin’den Gaziantep’teki gerginlik için vatandaşa sağduyu çağrısı”, “Gaziantep Misafirperver!”). ${ }^{133}$

Sağduyu söyleminin göndermede bulunduğu misafirlik durumunu değinen Derrida, ev sahibinin kendi evinde efendi olarak kalmasını ve yabancıya sunacağı mallar üzerindeki hükümdarlığından emin olmasının misafirperverlik yasası gibi durduğunu ve kültürümüz çerçevesinde sağduyu olarak göründügünü belirtir. ${ }^{134} \mathrm{Bu}$ anlamda sağduyu kavramının içerdiği geleneksel misafirperverlik miti, yabancıya duyulan saygıya, hoşgörüye gönderme yapan; ancak biz olanı olumlayan, yeniden üreten ve bizi diğerlerinden ayıran işlevselliğe sahiptir. ${ }^{135} \mathrm{Bu}$ bakımdan misafirlik söylemi içinde barındırdığı iktidar konumuyla Suriyeli mültecilerin umduğunu değil bulduğunu yemesi gerektiğini vurgulamaktadır. Böyle bir koşullu misafirperverlikte ev sahibi otoritesini korumakta; böylelikle sunulan armağanı kısıtlamaktadır.

\section{Sonuç}

Kant, evrensel misafirperverliği hak sorunu olarak içeriklendirmiş, yabancının ağarlanmasını merhamet, iyilikseverlik duygusunun ötesinde hukuksal bir bağlama oturtmuştur. Bu anlamda misafir yasal güvence altına alınmış, ev sahibi toplumun merhamet duygusuna bırakılmamıştır. Fakat Kant'ın misafirperverlik hakkını cumhuriyete dayalı toplulukların imtiyazı olarak görmesi ve bu hakkının tanınmasını egemenin insiyatifine bırakması "haklara sahip olma hakkı" açısından eksik kalmıştır. Aynı zamanda Kant, misafirperverlik hakkını geçici ikamet hakkı olarak sınırlandırmış ve sığınma talebinde bulunanların sadece can güvenliği bulunmadığ̣ durumlarda geri gönderilmeme zorunluğundan bahsetmiştir. Kant’ın söz konusu düşünceleri uluslararası sözleşmelerinin temelini oluşturmuştur. Uluslararası mülteci hukuku mültecilerin ağarlanmasına yönelik belli standartlar getirmiş, ancak

131 Mesut Yücebaş, “Gaziantep Yerel Basınında Suriyeli İmgesi Yeni Taşranın Suskunları: Suriyeliler”, Birikim Dergisi 311 (Mart 2015): 40.

132 "Hrant Dink Vakfı, Medyada Nefret Söylemi ve Ayrımcı Dil Eylül-Aralık 2014 Raporu”, son güncelleme 7 Ocak , 2017, http://hrantdink.org/attachments/article/274/HDV_ocak-nisan2014_rapor.pdf. 133 "Hrant Dink Vakfı, Medyada Nefret Söylemi ve Ayrımcı Dil Eylül-Aralık 2014 Raporu”.

134 Derrida, Bağışlama ve Kozmopolitizm, 28.

135 Yücebaş, “Gaziantep Yerel Basını” 38. 
mültecilerin korunması açısından yetersiz kalmıştır. Sı ̆̆ınma hakkının devletlerin tasarrufuna bırakıldığı Kantçı misafirperverlik düşüncesi bugün modern hukukta yerini almıştır; ancak devletler Kant’ın geri göndermeme ilkesini bile çiğnemektedir, mültecilere yönelik yasa ve politikalarında insan haklarından uzak, kısıtlayıcı bir tutum sergilemektedirler.

Türkiye'nin iltica düzenlemeleri ise aynı şekilde hak ve imkân açısından kısıtlıdır. Türkiye en başta Cenevre Sözleşmesi'ne coğrafi çekince ile taraf olup Avrupa d1şından gelenlere mülteci statüsü tanımamaktadır. Suriyeli mültecileri kapsamına alan Geçici Koruma Yönetmeliği acil ihtiyaçların giderilmesi şeklinde düzenlenerek geçicilik üzerine inşa edilmiştir.

Günümüzde egemen devletlerin uluslararası hukuku sınırlandırmasından ve "misafirsevmez" politikalar uygulamasından dolayı Derrida, mültecilerin, yerinden edilmişlerin sorunlarının çözümü için misafirperverlik kavramının devletle ilişkisinin yeniden sorgulanması gerektiğini belirtmiştir. Böylece misafirperverlik kavramını yapısöküme uğratan Derrida, misafirperverliğin sınırlarını, çelişkisini ve imkansızlığını ortaya koymuştur. Bu yeniden düşünme ile Derrida, hukuk ve kuralların olduğu yerde misafirperverliğin koşullu olduğunu dolayısıyla bu durumda misafirperverlikten bahsedilemeyeceğini söylemiştir. Misafirperverlik hukukunda yer alan koşulluğu aşmaya çalışabilmek, misafirperverlik hukukunu ideal hale getirebilmek için misafirperverlik etiğinin daima hedeflenmesi gerektiğini belirtmiştir. Yani Derrida, misafirperverlik etiğinin sınırsız oluşundan dolayı imkansız olduğunu bundan dolayı yasa ve politika yoluyla uygulanamayacağını; ancak yasaların iyileştirilmesinde esin kaynağı olabileceğini ifade etmiştir.

Derrida’nın misafirperverlik düşüncesini dikkate alarak, Türkiye'deki bazı gazetelerin haber başlıklarına ve raporlarla ortaya konan yerel halkın algısına baktığımızda Suriyeli mültecilere yönelik misafirlik söyleminin istilacı ve düşman imgesini içerdiği, biz ve onlar ayrımı yaptığı, ev sahibini olumladığı ve geçiciliği barındırdığ görülebilmiştir. Böylesi bir koşullu karşılama da iktidar konumu muhafaza edilmektedir ve hak ihlallerine yol açmaktadır. Misafirlik kavramının bu şekilde sınırlama kavramı olarak kullanılması Derrida’nın bahsettiği gibi misafirperverliği eşik kılmaktadır, yani misafirperverlik yoktur. Bu bakımdan Suriyeliler "bizler"in misafirleri değil, insan hakları bakımından mültecidirler.

\section{Kaynakça}

Agamben, Giorgio. Kutsal İnsan Egemen İktidar ve Çıplak Hayat. İstanbul: Ayrıntı Yayınları, 2013.

Bauman, Zygmunt. Sosyolojik Düşünmek. İstanbul: Ayrıntı Yayınları, 2015.

Benhabib, Seyla. Ötekilerin Hakları: Yabancılar, Yerliler, Vatandaşlar. İstanbul: İletişim Yayınları, 2014.

Bernasconi, Robert. Levinas Okumaları, Çev., Zeynep Direk. İstanbul: Pinhan, 2011. Biner, Özge. Türkiye’de Mültecilik: İltica, Geçicilik ve Yasallık “Van Uydu Şehir Örneği”. İstanbul: İstanbul Bilgi Üniversitesi Yayınları, 2016. 
BMMYK. Dünya Mültecilerinin Durumu 1997-1998: Bir İnsanlı Sorunu. Ankara: Numune Matbaası, 1997.

BMMYK. İltica, Uluslararası Göçve Vatansızlık: Kuram, Gözlem ve Politika. Ankara: Anıl Reklam Matbaacilık, 2011.

BMMYK, Sığınma ve Mülteci Konularındaki Uluslararası Belgeler ve Hukuki Metinler. Ankara: Damla Matbaası, 1998.

Cevheri Alpakgir, S.Gizem. "Mültecilik kavramının ve Mültecilerin Hukuki Durumuna Dair Sözleşmede Yer Alan Hakların Koşullu Misafirperverlik Üzerinden Değerlendirilmesi” III. Türkiye Lisansüstü Çalışmalar Kongresi Bildiriler Kitabı- III, Sakarya Üniversitesi, Sakarya, Mayıs 15-18, 2014.

Çelik, Abdurrahim, Mehmet Alkış, Sabri Sayan ve Yusuf Ekinci. Gaziantep’te Suriyelilere Yönelik Saldırılar ve Toplumsal Nefretin Sebeplerinin Analizine Dair Rapor, Mazlumder, Kasim 2014.

Çırakman, Elif. "Levinas'ta Öteki ve Adalet: Eleştirel Bir Not". Doğu Batı Düşünce Dergisi 4/13 (2000-01): 179-199.

Çiçekli, Bülent. Yabancılar ve Mülteci Hukuku. Ankara: Seçkin Yayıncılık, 2014.

Derrida, Jacques. “Ağırlama Sözcügü̈. MonoKL Levinas Özel Sayısı 4/ VIII-IX (2010): 562-576.

Derrida, Jacques. Bă̆ışlama ve Kozmopolitizm, Çev., Ali Utku-Mukadder Erkan. İstanbul: Birey yayıncılık, 2005.

Derrida, Jacques. Pera Peras Poros: Jacques Derrida ile Birlikte Disiplinlerarası Çalışma. İstanbul: Türkiye İş Bankası Yayınları, 2012.

Direk, Zeynep. Başkalık Deneyimi: Kıta Avrupası Felsefesi Üzerine Denemeler. İstanbul: Yapı Kredi Yayınları, 2005.

Duva, Özlem. "Evrensel Konukseverlik ve Haklara Sahip Olma Hakkı" Birinci Uluslararası Felsefe Kongresi: Eşitlik, Özgürlük ve Kardeşlik Bildirileri, Uludağ Üniversitesi Fen Edebiyat Fakültesi, Bursa, 14-16 Ekim, 2010.

Ekşi, Nuray. Avrupa İnsan Hakları Mahkemesi Abdolkhani ve Karimnia- Türkiye Davası Mülteci ve Sı̆̆ınmacı Hukuku Açısından Değerlendirme. İstanbul: Beta, 2010.

Erdoğan, Murat. Rapor: Türkiye'deki Suriyeliler: Toplumsal Kabul ve Uyum Araştırması. Hacettepe Üniversitesi Göç ve Siyaset Araştırmaları Merkezi, Kasım 2014.

Ergüven, Nasıh Sarp ve Beyza Özturanlı. "Uluslararası Mülteci Hukuku ve Türkiye”. Ankara Üniversitesi Hukuk Fakültesi Dergisi, 62: 4 (2013), 1007-1061. (Erişim 10.09.2016).

Google. "Hrant Dink Vakfı, Medyada Nefret Söylemi ve Ayrımcı Dil Ocak- Nisan 2014 Raporu”. Son güncelleme 7 Ocak, 2017. http://hrantdink.org/attachments/ article/274/HDV_ocak-nisan2014_rapor.pdf.

Google. "Syria Emergency”. Son güncelleme 29 Ekim, 2016. http://www.unhcr.org/ syria-emergency.html.

Google. "Syria Regional Refugee Response”. Son güncelleme 29 Ekim, 2016. http:// data.unhcr.org/syrianrefugees/regional.php. 
Google. “UNHCR Global Trends Report”. Son güncelleme 11 Temmuz, 2016. http:// www.unhcr.org/trends2013/.

Güleç, Cansu. “Avrupa Birliği'nin Göç Politikaları ve Türkiye’ye Yansımaları”. Tesam Akademi Dergisi 2/2 (2015): 81-100.

Gültekin, Ahmet Cüneyt. "Bağışlanan konukseverlik ve Konuksever Bağışlama: Derrida Felsefesinde Etik (Olanaksız) ve Politika (Olanaklı) İlişkisi”. Felsefe ve Sosyal Bilimler Dergisi 17 (2014 Bahar), 13-34. (Erişim 21.08.2016).

Helsinki Yurttaşlar Derneği. Saha: Göçmenlerin Aynasında Türkiye. İstanbul: Mart Matbaa, 2016.

İçduygu, Ahmet, Sema Erder ve Ömer Faruk Gençkaya. Türkiye’nin Uluslararası Göç Politikaları 1923-20023: Ulus Devlet Oluşumundan Ulus Ötesi Dönüşümlere. İstanbul, MireKoç, Ocak 2014.

Kant, Immanuel. Edebi Barış Üzerine Felsefi Deneme, Çev., Yavuz Abadan ve Seha L. Meray. Ankara: Ajans Türk Matbaası, 1960.

Kearney, Richard. Yabancılar, Tanrılar ve Canavarlar: Ötekiliği Yorumlamak. Çev., Barış Özkul. İstanbul: Metis Yayınları, 2012.

Keneş Çoban, Hatice. "Metaforun Ayrımcı Hegemonyanın İnşasındaki Rolü: Suriyelilerin Haberleştirilmesinde Metafor Kullanımı". Gaziantep Sosyal Bilimler Dergisi 15/2 (2016): 253-280.

Kibar, Sibel. "Levinas'ta Adaletin Terazisi Yok!”. MonoKL Levinas Özel Sayısı 4/VIIIIX (2010): 441-449.

Kirişçi, Kemal. Rapor: Misafirliğin Ötesine Geçerken Türkiye’nin Suriyeli Mülteciler Sınavı. Çev., Sema Karaca, Brooking Enstitüsü ve USAK, Haziran 2014.

Levinas, Emmanuel. Sonsuza Tanıklı: Emmanuel Levinas'tan Seçme Yazılar. Haz., Zeynep Direk ve Erdem Gökyaran. İstanbul: Metis Yayınları, 2010.

Naas, Michel. "Alors, qui êtes-vous? Jacgues Derrida ve Konukseverlik Sorusu". Cogito 47-48 (2006): 236-250.

Odman, Tevfik. Mülteci Hukuku. Ankara: İmaj Yayınları, 1995.

Ökten, Kaan Harun. "Immanuel Kant’ın Edebi Barış Üzerine Felsefi Deneme Adlı Eseriyle Ortaya Koyduğu Edebi Barış Fikri ve Bu Fikrin Uluslararası İlişkiler Düşüncesinde Yarattığı Etki”. Doktora Tezi, İstanbul Üniversitesi, 2001.

Peker, Bülent ve Mithat Sancar. Mülteciler ve İltica Hakkı: Yaşamın Kıyısındakilere Hoşgeldin Diyebilmek. Ankara: İnsan Hakları Derneği Yayınları, 2001.

Savaşan, Zerrin. “AB’de Sığınma Hakkı: Ortak Sığınma Sistemi Oluşturma Amacı ve Devam Eden Kısitlamalar", TODAİE İnsan Hakları Yıllı̆̆ı, 27 (2009), 13-34. (erişim 27.10.2016)

Soysal Özgür. “Evrenselcilik - Tikelcilik Gerilimi Işı̆̆ında Ötekiler’in Kaderi”. Birinci Uluslararası Felsefe Kongresi: Eşitlik, Özgürlük ve Kardeşlik Bildirileri, Uludağ Üniversitesi Fen Edebiyat Fakültesi, Bursa, 14-16 Ekim, 2010.

Şallı, Saim. "Kant’ın Kozmopolitizm Teorisi ve Çağdaş Kozmopolitizm Akımı Üzerindeki Etkisi”. Doktora Tezi, Gazi Üniversitesi, 2011. 
Tunç, Serpil. "Konukseverlik: Hukukta ve Hukukun Ötesinde" Birinci Uluslararası Felsefe Kongresi: Eşitlik, Özgürlük ve Kardeşlik Bildirileri, Uludağ Üniversitesi Fen Edebiyat Fakültesi, Bursa, 14-16 Ekim, 2010.

Uluslararası Af Örgütü, Rapor: Hayatta Kalma Mücadelesi: Türkiye'deki Suriye'den Gelen Mülteciler, Kasım 2014.

Ünal, Sedar. "Türkiye’nin Beklenmedik Konukları: "Öteki Bağlamında Yabancı Göçmen ve Mülteci Deneyimi”, Zeitschrift für die Welt der/Türken journal of World of Turks 6/3 (2014): 65-89.

Yeğenoğlu, Meyda. Avrupa'da İslam, Göçmenlik ve Konukseverlik. İstanbul: İstanbul Bilgi Üniversitesi Yayınları, 2016.

Yücebaş, Mesut. “Gaziantep Yerel Basınında Suriyeli İmgesi Yeni Taşranın Suskunları: Suriyeliler”. Birikim Dergisi 311 (Mart 2015): 38-47. 


\title{
The View of Syrian Refugees as a "Guest" in terms of Hospitality Law and Ethics
}

\author{
CEYLAN LORTOĞLU
}

\begin{abstract}
In this paper, the concept of hospitality is examined in terms of Kant's law of hospitality and Derrida's philosophy of hospitality inspired by Levinas, and discourse of hospitality for Syrian ferugees is discussed in the spirit of Derrida's hospitality. The right of refugees have been limited to the initiative of the states in international conventions which are inspired by Kantian peace theory. Nowadays, when we look at sovereign states, it is seen that they are limiting international law and passing laws and regulations preventing refugees from crossing borders. Turkey, which is a party of Geneva Convention with the condition of the geographical restriction, has also provided restrictions on the asylum law and policy. The temporary protection regulation for Syrian refugees is regulated for the principle temporariness and urgent needs of refugees. Derrida, tries to experience a way instead of the law and politics that care of interests of states that are far from human rights, questions how laws and policies can be made more hospitable. In this contect, he deconstructs the concept of hospitality and reveals the aporetic, contradictory and impossible structure of the concept. Considering Derrida's concept of hospitality, the discourse of hospitality regarding Syrian refugees involves controversy, temporariness, and impression of enemy and invader. Hence, the discourse creates a division between "us and them", which is visible in the press and public opinion. Derrida states that such a conditional hospitality that protects the interests of the government is a door or threshold, so it is not an exact hospitality.
\end{abstract}

Keywords: Kant, Derrida, Levinas, Hospitality, Ethic, Law, Syrian refugee. 